This manuscript has been submitted for publication in Paleoceanography-Paleoclimatology. It has not yet undergone peer review and will probably change somewhat before it is accepted. If accepted, the final version of the manuscript will be available via the "Peer-reviewed Publication DOI" link on the EarthArXiv page. Please feel free to contact the authors with feedback.

\title{
Early Paleocene Paleoceanography and Export Productivity in the Chicxulub Crater
}

Christopher M. Lowery ${ }^{1 *}$, Heather L. Jones ${ }^{2}$, Tim Bralower ${ }^{2}$, Ligia Perez Cruz ${ }^{3}$, Catalina Gebhardt $^{4}$, Michael T. Whalen ${ }^{5}$, Elise Chenot ${ }^{6}$, Jan Smit ${ }^{7}$, Marcie Purkey Phillips ${ }^{1}$, Konstantin Choumiline $^{8}$, Ignacio Arenillas ${ }^{9}$, Jose A. Arz ${ }^{9}$, Fabien Garcia ${ }^{10}$, Myriam Ferrand ${ }^{10}$, Sean P.S. Gulick $^{1,11}$, Exp. 364 Science Party ${ }^{12}$

${ }^{1}$ Institute for Geophysics, Jackson School of Geosciences, University of Texas at Austin, USA

${ }^{2}$ Department of Geosciences, Pennsylvania State University, University Park, USA

${ }^{3}$ Instituto de Geofísica, Universidad Nacional Autónoma De México, Ciudad de México, México

${ }^{4}$ Alfred Wegener Institute Helmholtz Centre of Polar and Marine Research, Bremerhaven, Germany

${ }^{5}$ Department of Geosciences, University of Alaska Fairbanks, USA

${ }^{6}$ Géosciences Montpellier, Université de Montpellier, France

${ }^{7}$ Faculty of Earth and Life Sciences (FALW), Vrije Universiteit Amsterdam, Netherlands.

${ }^{8}$ Department of Earth Sciences, University of California Riverside, USA

${ }^{9}$ Departamento de Ciencias de la Tierra and Instituto Universitario de Investigación en Ciencias

Ambientales de Aragón, Universidad de Zaragoza, E-50009, Spain

${ }^{10}$ Biogéosciences, Université de Bourgogne Franche-Comté, France

${ }^{11}$ Center for Planetary Systems Habitability, Jackson School of Geosciences, University of Texas at

Austin, USA

${ }^{12}$ See Appendix 1

*Corresponding author: Christopher Lowery (cmlowery@utexas.edu)

\section{Key Points}


- Export productivity in the Chicxulub crater was high for the first $320 \mathrm{kyr}$ after the K-Pg boundary, then declined for the next $900 \mathrm{kyr}$

- The final decline in export productivity is associated with the turnover of calcareous nannoplankton disaster assemblages

- Export productivity change is not correlated to stratification or terrigenous input and was likely driven to turnover in phytoplankton community

\section{Abstract}

The Chicxulub impact caused a crash in export productivity in much of the world's oceans which contributed to the extinction of $75 \%$ of marine species. In the immediate aftermath of the extinction, local export productivity was highly variable, with some sites, including the Chicxulub crater, recording elevated export production. The long-term transition back to more stable export productivity regimes has been poorly documented. Here, we present elemental abundances, foraminifer and calcareous nannoplankton assemblage counts, total organic carbon, and stable carbon isotopes from the Chicxulub crater to reconstruct long-term changes of productivity over the first $3 \mathrm{Myr}$ of the Paleocene. We show

44 that export production was elevated for the first $320 \mathrm{kyr}$ of the Paleocene and then declined over the next 900 kyr, remaining low thereafter. This interval is associated with fluctuations in water column stratification and terrigenous flux, but these variables are uncorrelated to export productivity. Instead, we

47 suggest that the turnover in the phytoplankton community from a post-extinction assemblage dominated 48 by picoplankton (which promoted nutrient recycling in the euphotic zone) to a more normal Paleocene 49 pelagic community dominated by calcareous nannoplankton (which more efficiently removed nutrients 50 from surface waters and led to oligotrophy) is responsible for the decline in export production in the 51 southern Gulf of Mexico.

\section{Plain Language Summary}


The end Cretaceous mass extinction was caused by the impact of an asteroid on what is today the

54 Yucatán Peninsula, Mexico. The impact ejected aerosols and dust into the air that reduced sunlight

55 transmission, causing a severe decline in photosynthesis and the collapse of marine food webs. However,

56 the change in the amount of food created by photosynthesizing plankton that makes it to the seafloor

57 (export productivity) was variable across the oceans. At some places, including the Chicxulub crater,

58 export productivity was actually high immediately after the impact. We produced a $\sim 3$ million year record

59 of export productivity in the crater to determine how long it remained elevated and why it eventually

60 declined. Export production was very high for the first 320,000 years after the impact and remained

61 elevated for the next 900,000 years. We found that this production was not related to the input of nutrients

62 via rivers around the Gulf of Mexico or how stratified the ocean was, but was probably driven by the

63 change in the cell size of phytoplankton and its impact on export over the first million years of the

64 Paleocene.

Keywords: K-Pg, Chicxulub Crater, Paleoproductivity, Foraminifera, Nannoplankton, Paleocene

\section{Introduction}

At the end of the Cretaceous Period (66.0 Ma), the impact of an asteroid on the Yucatán carbonate platform in the southern Gulf of Mexico caused the extinction of $75 \%$ of marine species

69 (Alvarez et al., 1980; Smit et al., 1980; Hildebrand et al., 1991; Jablonski, 1995; Schulte et al., 2010),

70 including $~ 90 \%$ of pelagic calcifiers such as planktic foraminifera and calcareous nannoplankton (Bown,

71 2004; Fraass et al., 2015; Lowery et al., 2020). Dust and sulfate aerosols ejected from the evaporite-rich

72 carbonate target rock and soot from widespread wildfires blocked the sun, resulting in severe short-term

73 cooling (Wolbach et al., 1985; Pope et al., 1994; Vellekoop et al., 2014, 2016; Bardeen et al., 2017

74 Brugger et al., 2017; Artemieva et al., 2017; Gulick et al., 2019; Artemieva and Morgan, 2020) and

75 collapse of the food chain due to a sharp decline in photosynthesis (Zachos et al., 1989; D'Hondt et al.,

76 1998; Kring, 2007). These effects were short-lived, however, as most dust, soot, and aerosols were

77 removed from the atmosphere on the order of years (Brugger et al., 2017; Tabor et al., 2020), and the 
oceans quickly became hospitable for life, even at ground zero in the Chicxulub crater (Lowery et al., 2018). Recent work quantifying oceanic $\mathrm{pH}$ changes across the K-Pg boundary has shown that postimpact ocean acidification lasted for $\sim 40 \mathrm{kyr}$, and returned to pre-event values within $80 \mathrm{kyr}$, after a period of overshoot (Henehan et al., 2019). Meanwhile, temperature proxies and modelling data indicate that Deccan volcanism in the early Paleocene was insufficient to negatively impact early recovery ecosystems (Hull et al., 2020).

Given the short duration of adverse environmental conditions in the earliest Paleocene, it is puzzling that global marine productivity took at least 1.8 myr to recover to pre-extinction levels (e.g., Hsü and McKenzie, 1985; Zachos et al., 1989; D’Hondt and Zachos, 1998; Coxall et al., 2006; Birch et al., 2016). The collapse of export productivity at the K-Pg boundary has been observed via the vertical gradient of $\delta^{13} \mathrm{C}$ between the surface ocean and seafloor. Under normal conditions, the sinking of ${ }^{12} \mathrm{C}$ enriched organic carbon (termed the "biological pump" and primarily driven by the sinking remains of dead plankton) from the euphotic zone to the deep sea leaves the surface ocean enriched in ${ }^{13} \mathrm{C}$ and the seafloor depleted in ${ }^{13} \mathrm{C}$. The post-K-Pg collapse in this gradient can be explained by a $50 \%$ reduction in the amount of organic matter exported from the euphotic zone (D'Hondt et al., 1998; Alegret et al., 2012; Henehan et al., 2019) or less, if part of the signal is from extinction-related changes in planktic foraminifer shell geochemistry (e.g., the extinction of photosymbiont-bearing planktics; Alegret et al., 2012; Birch et al., 2016). However, the exact mechanisms which controlled the eventual recovery of productivity and the relationship between the recovery of export production and the recovery of marine ecosystems remain unclear.

While carbon isotopes record the global average change in the strength of the biological pump, biogenic barium is a paleoproductivity proxy which correlates with local organic matter flux from overlying surface water (e.g., Griffith and Paytan, 2007). Barium proxy data indicates that export production did not uniformly decline across the oceans after the Chicxulub impact, as some sites actually show an increase (Hull and Norris, 2011). Broadly, sites from a range of water depths in the Gulf of 
Mexico/North Atlantic/Tethys region record reduced export production in the early Danian (Alegret et al.,

104 2001; Esmery-Senlet et al., 2015; Vellekoop et al., 2017), whereas sites in the central Pacific record

105 increased export production during the same time period (Hull and Norris, 2011). A new earliest Danian

106 record from the peak ring of the Chicxulub crater at International Ocean Discovery Program (IODP) Site

107 M0077 revealed that the crater itself experienced high export productivity within foraminifer biozone P $\alpha$,

108 within a few 10s of kyrs of the impact (Lowery et al., 2018). However, it was unclear how long high

109 export productivity persisted at ground zero or how it relates to global patterns of heterogeneous export

110 production in the early Danian. Was this locality oceanographically pre-disposed to high export

111 productivity, or did changing conditions eventually lead to a decline? If so, what conditions shifted to

112 cause lower export production? Jones et al. (2019) found that calcareous nannoplankton "disaster

113 assemblages" persisted in the crater for approximately 1 myr post impact, well after they were replaced

114 by incoming Paleocene taxa at other sites. Interestingly, the turnover from disaster assemblages to a

115 succession of acmes of novel Paleocene nannoplankton species in the crater is associated with a shift in

116 surface waters from eutrophic to oligotrophic conditions (Jones et al., 2019). Jones et al. (2019)

117 speculated that these changes in the populations of primary producers are related to changes in export

118 productivity, but lacked the data to test this, or determine what may have caused those changes.

Here, we compare the calcareous nannoplankton record of Jones et al. (2019) to planktic and

120 benthic foraminifera, and major, minor, and trace elements to reconstruct export productivity, water

121 column stratification, terrigenous flux, and phytoplankton population change during the early Paleocene

122 interval (66.0-62.5 Ma) of IODP Site M0077 in the Chicxulub crater (Figure 1) in order to document the

123 overall paleoceanographic evolution of the Chicxulub crater and to determine how long export production

124 remained elevated after the K-Pg boundary. We then evaluate two competing hypotheses about the causes

125 of the eventual decline in export production: environmental changes in the southern Gulf of Mexico or

126 changes in the plankton ecosystem.

\section{2. Material and Methods}


In 2016, IODP/ICDP Expedition 364 drilled the peak ring of the Chicxulub crater (Morgan et al., 129 2017), coring over $100 \mathrm{~m}$ of post-impact Paleogene sediments with nearly $100 \%$ recovery. Ten meters of

130 Paleocene pelagic carbonates were recovered at the base of the post-impact section, conformably

131 overlying the top of the impact breccia. The uppermost $40 \mathrm{~cm}$ of these pelagic carbonates is cut by three 132 disconformities and spans the middle and late Paleocene; the rest of the section, the focus of this study, 133 spans the earliest to middle Paleocene, and is continuous from 66 to $\sim 62 \mathrm{Ma}$ (Morgan et al., 2017).

\subsection{Microfossils}

Samples for foraminiferal analysis were crushed with mortar and pestle into mm-sized pieces and then soaked in a solution of peroxide and borax for at least one week. They were then sieved over a 45

$137 \mu \mathrm{m}$ mesh to ensure recovery of generally small Paleocene taxa (care was taken to avoid juveniles in the 138 counts, but many mature specimens - i.e., with multiple whorls - smaller than the more common $63 \mu \mathrm{m}$ 139 cutoff were present). The sieve was soaked in methylene blue dye between samples to identify any 140 contamination. Sieved samples were dried in an oven and then split in a microsplitter to obtain a 141 manageable number of foraminifera. At least 300 individuals were picked per sample. Additional

142 specimens were extracted using a solution with $80 \%$ acetic acid and $20 \% \mathrm{H}_{2} \mathrm{O}$, following the procedure of 143 Lirer (2000). The best-preserved of these were imaged with the Zeiss MERLIN Field Emission Scanning 144 Electron Microscope (FESEM) at the Universidad de Zaragoza.

\subsection{XRF Core Scanning}

Split cores were scanned with an AVAATECH XRF Core Scanner II at the University of

147 Bremen. The split core surface was covered with a 4- $\mu \mathrm{m}$ thick SPEXCerti Prep Ultralenel foil to avoid 148 contamination of the core material. Data were collected with a Canberra X-PIPS Silicon Drift Detector 149 (Model SXD 15C-1150-500) with a $1550 \mathrm{eV}$ X-ray resolution, the Canberra Digital Spectrum Analyzer 150 DAS 1000, and an Oxford Instruments 50W XTF5011 X-Ray tube with rhodium target material, and ray 151 data were processed using the iterative least squares software WIN AXIL from Canberra Eurisys. To 
152 obtain sufficient resolution, we used a slit-size of $12 \mathrm{~mm}$ and a step-size of $10 \mathrm{~mm}$. We conducted three

153 line-scans to determine a range of element concentrations across the core section. For the first scan, we 154 used an accelerating voltage of $50 \mathrm{kV}$ and a beam current of $1 \mathrm{~mA}$ with a sampling time of 20 seconds to 155 determine the concentrations of $\mathrm{Ba}$ and $\mathrm{Sr}$. For the second scan, we used an accelerating voltage of $30 \mathrm{kV}$ 156 and a beam current of $1 \mathrm{~mA}$ with a sampling time of 20 seconds to determine the concentrations of $\mathrm{Sr}$,

$157 \mathrm{Rb}, \mathrm{Zr}, \mathrm{Zn}, \mathrm{Pb}$, and Ni. For the third scan, we used an accelerating voltage of $10 \mathrm{kV}$ and a beam current of $1580.15 \mathrm{~mA}$ with a sampling time of 20 seconds to determine the concentrations of $\mathrm{Al}, \mathrm{Si}, \mathrm{K}, \mathrm{Ca}, \mathrm{Ti}, \mathrm{Fe}, \mathrm{Mn}$, 159 and $\mathrm{S} . \mathrm{Ba}, \mathrm{Ti}, \mathrm{Al}, \mathrm{Fe}$, and $\mathrm{Ca}$ scans are reported here.

\subsection{Total organic carbon}

Total organic carbon (TOC) was determined by measuring the difference between total carbon

162 (TC) and total inorganic carbon (TIC). TC and TIC were determined via ignition and acidification, 163 respectively, both of which produced $\mathrm{CO}_{2}$ which was quantified with the infrared analyzer on an ELTRA 164 CS500 carbon sulfur analyzer, with analytical error of $<2 \%$.

\subsection{Carbon Stable Isotopes}

Bulk rock samples were taken every $5 \mathrm{~cm}$ for stable isotope analysis at the Biogéosciences

167 Laboratory, University of Bourgogne Franche-Comté, Dijon, France. Samples were crushed in an agate

168 mortar and pestle into fine and homogeneous calcite powders, which were reacted with $100 \%$ phosphoric

169 acid at $70^{\circ} \mathrm{C}$ using a ThermoScientific DELTA V PLUS mass spectrometer, connected to a Kiel IV

170 carbonate preparation device. All isotopic values are reported in the standard $\delta$-notation in per mil relative

171 to VPDB (Vienna Pee Dee Belemnite) by assigning a $\delta^{13} \mathrm{C}$ value of $+1.95 \%$ o to NBS19. External

172 reproducibility as determined by replicate analyses of laboratory standards was $\pm 0.04 \%$ ( $2 \sigma)$ for carbon 173 isotopes.

174 3. Results

$175 \quad 3.1$ Age Model 
177 (Gulick et al., 2017). Calcareous nannofossil taxonomy is based on the CP zonation scheme of Okada and 178 Bukry (1980) following the taxonomic concepts of Perch-Nielsen (1985) and Bown (1998). Planktic 179 foraminifer biostratigraphy is based on the P zones of Berggren and Pearson (2005) as modified by Wade 180 et al. (2011), following the taxonomic concepts of Olsson et al. (1999) and Pearson et al. (2006). Key 181 planktic foraminifer taxa are illustrated in Figure 3. Calibrated ages assigned to each datum are those 182 reported in Appendix 3 of the Geologic Time Scale 2012 (Gradstein et al., 2012). Samples were taken at 2 $183 \mathrm{~cm}$ increments from 616.2 -616.6 mbsf, and $5 \mathrm{~cm}$ increments above that. Paleomagnetic reversals are not 184 included in the age model because a heterogenous chemical remnant re-magnetization occurred 185 throughout the study interval obscuring the original polarity (Morgan et al., 2017; Gulick et al., 2019).

Although planktic foraminifera are abundant and diverse throughout the study interval, calcareous nannoplankton are rarer and much less diverse in the Paleocene interval of Site M0077, and form globally diachronous acmes for approximately 2 million years following the K-Pg mass extinction (Jones et al., 2019). Nannoplankton zonal markers at Site M0077 are either absent (tops of CP2 and CP3) or inconsistent with the planktic foraminifer datums (Tops of CP1 and CP4) (Figure 2). On the other hand, first and last occurrences of biostratigraphically significant planktic foraminifera taxa occur in the correct 192 order and seem to indicate relatively constant sedimentation over the study interval (from the base of the 193 Paleocene to planktic foraminifer biozone P2). Additionally, planktic foraminifer acme events (e.g., 194 Arenillas et al., 2000) also occur within the expected planktic foraminiferal biozones at Site M0077. For 195 these reasons, we consider the nannofossil datums which do occur at Site M0077 to be unreliable for age 196 control and did not include them in the age model. We are confident the first and last occurrence datums 197 of planktic foraminifera in the Chicxulub crater are coeval with those in the global ocean, and thus we 198 have used planktic foraminifer biozones listed in Table 1 to construct the age model.

\subsection{M0077 Sedimentology and Terrigenous Flux}


201 dilution by terrigenous material (Figure 4). Magnetic susceptibility is a common tool to determine the 202 terrigenous component in pelagic carbonates (e.g., Liu et al., 2012), although without determining the 203 source of magnetic signal it loses some nuance, and so we use elemental data to provide more detail. Iron 204 is generally correlated with terrigenous flux, while calcium is primarily sourced from biogenic carbonate 205 (Rothwell and Croudace, 2015). Both $\mathrm{Fe}$ and $\mathrm{Ca}$ are often used to infer carbonate dissolution in deep sea cores, particularly during the Paleogene, which was characterized by discrete episodes of $\mathrm{CO}_{2}$ release, 207 warming, and ocean acidification (Bralower et al., 2002; Edgar et al., 2007; Quillévéré et al., 2008; 208 Coccioni et al., 2010). However, we conclude that Fe and Ca variations at Site M0077 are driven by changes in dilution rather than dissolution because: (1) the site is relatively shallow $(\sim 700 \mathrm{~m})$ water depth 210 in the Paleocene (Lowery et al., 2018), well above the early Paleocene lysocline; and (2), intervals of 211 elevated $\mathrm{Fe} /$ depressed $\mathrm{Ca}$ do not correspond to intervals of reduced foraminifer preservation (Figure 5).

212 Core material at Site M0077 is strongly lithified, and had to be broken down with a mortar and pestle 213 prior to soaking. An unfortunate side effect of this aggressive disaggregation is the fracturing of some 214 portion of the foraminiferal tests. We did not distinguish foraminifera broken in this way from fragments 215 of foraminifera which may have experienced partial dissolution on the seafloor due to deposition below 216 the lysocline, a common proxy for ocean acidification ("Foram Fractionation Index;" Thunell 1976). In 217 order to establish some quantitative proxy for foraminifer preservation, we instead report the number of 218 individuals in each counted population that could not be identified to the genus level. These "planktic 219 spp." are excluded from population analysis (other than planktic/benthic ratio) but provide a useful 220 approximation of preservation, with more unidentifiable individuals indicating worse preservation. Figure 2215 shows the lack of correlation between foraminifer preservation and $\mathrm{Fe}$ and $\mathrm{Ca}$, and thus we interpret 222 variations in Fe as a proxy for terrigenous flux and not dissolution. Additionally, Ti/Al ratios are often 223 used to determine the relative contributions of fluvial and aeolian processes, as Ti is often associated with 224 coarser size fractions delivered by fluvial processes and Al with small, clay-sized material blown to sea as 225 dust (e.g., Ziegler et al., 2009; Govin et al., 2012). 
Large variations in terrigenous flux are evident in the Paleocene interval of Site M0077 (Figure

227 4). Overall, terrigenous flux was low for the first $~ 1$ Myr of the Danian and higher thereafter. Numerous 228 shorter peaks are superimposed on this long-term trend. The base rate of terrigenous flux, particularly 229 measured in Fe, is very low below $615.6 \mathrm{mbsf}$ (65.4 Ma), has an initial peak at $615.0 \mathrm{mbsf}(65.2 \mathrm{Ma})$, 230 decreases somewhat, and then remains relatively elevated for the rest of the study interval. It should be

231 noted that the closest land was > $500 \mathrm{~km}$ to the west in modern central Mexico (Gulick et al., 2019), and 232 thus terrigenous material only slightly diluted the pelagic carbonate at Site M0077. Ti/Al is positively 233 correlated with Fe (Figure 4), indicating that intervals of increased terrigenous flux to Site M0077 were 234 driven by periods of enhanced fluvial input to the Gulf of Mexico. Thus, changes in terrigenous flux are a useful proxy for changes in continental weathering in the Gulf of Mexico basin.

\subsection{Water Column Structure}

Planktic foraminiferal paleoecology provides insight into local hydrography. Planktic foraminifera occupy specific depth habitats in open ocean environments which can be determined via single-species isotopic analysis (e.g., Aze et al., 2011; Birch et al., 2012). The pervasive foraminiferal recrystallization throughout Site M0077 prevents this kind of geochemical analysis, but fortunately we can use the Paleocene compilation of Aze et al. (2011) and other published records to assign the species to depth habitats (Table 2). The use of planktic foraminifer populations to reconstruct water column stratification is fairly common, particularly the relative abundance of deeper dwelling taxa (e.g., Leckie et

244 al., 2002; D’Onofrio et al., 2016; Lowery et al., 2020). Here, we use the relative proportion of mixed 245 layer, thermocline, and sub thermocline taxa to reconstruct the degree to which the water column was 246 stratified (Figure 6). Dominance of mixed layer taxa indicates the lack of suitable habitat for 247 thermocline/subthermocline species, suggesting weak stratification with the mixed layer habitat extending 248 through much of the photic zone. Higher abundances of thermocline and subthermocline taxa indicate a more stable habitat for these species, which may result from stronger water column stratification. 
Conversely, a dominance of mixed layer taxa may indicate a lack of strong vertical stratification with no

251 habitat for organisms which live below stratified layers.

Overall, Site M0077 is dominated by mixed layer taxa for the first $200 \mathrm{kyr}$ of the Danian,

253 followed by a shift to more stratified waters from 200-400 kyr (616.3-615.9 mbsf) after the boundary, a

254 return to mixed-layer dominated waters from 400-900 kyr (615.9-614.9 mbsf) after the boundary, and

255 finally a more permanent shift toward stable stratified waters after $900 \mathrm{kyr}$ (above $614.9 \mathrm{mbsf}$ ) (Figure 6).

256 Schaefer et al. (2020) found biomarker evidence for intermittent photic zone euxinia beginning around 1

257 myr after the K-Pg boundary, just above the level where we find the final shift to stable stratified waters.

258 Photic zone euxinia implies a lack of downward mixing of oxygenated surface waters, providing

259 additional evidence for increased stratification. The lack of evidence for photic zone euxinia below this

260 level suggests that poor stratification eliminated habitat space for thermocline and subthermocline species

261 in intervals dominated by mixed layer taxa.

\section{3.4 Export Productivity}

Export production, the removal of organic matter from the euphotic zone to the deep sea, is

264 primarily driven by the biological pump, in which organic matter is moved downward via biological 265 pathways like sinking, fecal pellets, the daily vertical migration, etc. (Zhang et al., 2018). The pump is 266 usually described as having two parts: the export of net primary production out of the euphotic zone (

$267100 \mathrm{~m} \mathrm{depth}$ ) and the scavenging and remineralization of that organic carbon as it sinks to the seafloor, or

268 at least deep enough to be removed from the short-term carbon cycled ( $1000 \mathrm{~m}$ depth) (e.g., Boyd and

269 Newton, 1995; Buessler, 1998; Legendre and Rivkin, 2002; Boyd and Trull, 2007; Buessler and Boyd,

270 2009; Henson et al., 2012). The amount of organic matter exported from the euphotic zone is often

271 referred to as "export efficiency" (e.g., Buessler and Boyd, 2009) or pump "strength" (e.g., Henson et al.,

272 2012), and the amount of organic matter that sinks below $1000 \mathrm{~m}$ is called "transfer efficiency" (Buessler

273 and Boyd, 2009) or pump "efficiency" (Henson et al., 2012); we opt to use strength vs. efficiency here 
274 (Henson et al., 2012). In the modern ocean these variables can be directly measured via satellites and

275 water sampling, but in paleoceanographic studies we can only indirectly reconstruct export production via 276 sedimentary proxies.

Biogenic barium, primarily preserved in marine sediments as barite $\left(\mathrm{BaSO}_{4}\right)$, strongly correlates

278 with modern export production (Dymond et al., 1992; Francois et al., 1995; Eagle et al., 2003; Paytan and

279 Griffith, 2007) and is thus a commonly used export productivity indicator (e.g., Payton et al., 1996; Bains

280 et al., 2000; Griffith and Paytan, 2012). Barite is primarily formed in marine environments during the

281 remineralization of sinking organic matter, but it can also be sourced from terrigenous sediments.

282 Therefore, barium is normalized to the terrestrially-sourced element titanium (Dymond et al., 1992;

283 Paytan and Griffith, 2007). This "excess barium" proxy has been used to reconstruct export production in 284 the early Paleocene using XRF data (Hull and Norris, 2011), as we do in this study. Different continental 285 drainage basins may have differing $\mathrm{Ba} / \mathrm{Ti}$ ratios, and thus long-term changes in sediment source area or dust vs. riverine flux may complicate interpretation of export productivity (Payton and Griffith, 2007).

287 However, significant changes in the sediment source to the southern Gulf of Mexico did not occur until the Laramide Orogeny, which began in the late Paleocene and therefore would not have influenced early Paleocene sedimentation (Galloway et al., 2000). Shorter term sedimentation changes related to impactdriven land denudation (e.g., Tschudy et al., 1984) were on the order of 8-20 kyr (Vajda et al., 2004), too

291 brief to explain the trends we observe. Because sediment is exclusively pelagic limestone, we consider 292 sedimentary source changes to be an unlikely driver of observed trends in biogenic barium. Another 293 possible source of barium in our study area is from the crater hydrothermal system, which was active 294 throughout our study interval, and which caused the precipitation of secondary barite in pore fluids in the 295 underlying impact breccia (Kring et al., 2020). We also regard this as an unlikely source of Ba enrichment 296 in the pelagic Paleocene sediments we examine here because secondary barite is only observed in the 297 impact breccia, meters below the contemporary Danian seafloor (Kring et al., 2020). Additionally, Ba is 298 only enriched in the lower few meters of the post impact sediments, while other hydrothermal elements 
are enriched throughout our study interval, indicating that the hydrothermal system was active for millions of years after the crater formed (Kring et al., 2020) and that Ba was not supplied to the seafloor by this mechanism.

While $\mathrm{Ba} / \mathrm{Ti}$ ratios can tell us about the overall strength and efficiency of the whole biological pump, foraminifer ecology can help us understand some of its component parts. Planktic foraminifera live in the upper water column and record conditions related to primary production. Paleocene planktic foraminifer taxa exhibit adaptations which allows them to make some groups better adapted to different levels of primary productivity. In the early Danian, some new genera (Eoglobigerina and the Subbotinids) evolved spines, long protrusions of calcite which provide an anchor for rhizopods (i.e., feeding microperforate and smooth normal perforate planktic foraminifera (in the Paleocene, these include Guembelitria, Globoconusa, Parvularugoglobigerina, Woodringina, Chiloguembelina, etc.) are unable to eat zooplankton, which are generally able to free themselves from unsupported rhizopodal networks; these foraminifera are primarily grazers, feeding on phytoplankton and any organic detritus that drifts by

314 (Hemleben et al., 1991). In the modern ocean, photosymbiont-bearing planktic foraminifera tend to dominate in oligotrophic subtropical gyres (e.g., Hemleben et al., 1991). Photosymbiosis existed in 316 planktic foraminifera in the Cretaceous but all those groups went extinct at the K-Pg boundary, and the 317 strategy re-evolved several million years later at the end of our study interval, beginning with Praemurica 318 inconstans and followed by Acarinina, Morozovella, and Igorina (Norris, 1996; Birch et al., 2012).

319 Spinose and symbiont-bearing planktic foraminifera are better adapted to food-limited environments, and 320 should be predominant in oligotrophic waters. On the other hand, non-spinose, non-symbiont bearing 321 planktics, the grazers, are best adapted to eutrophic environments, and should be dominant there. Benthic foraminifera are also powerful paleoenvironmental indicators. They are primarily 323 sensitive to changes in dissolved oxygen and food supply (Jorissen et al., 1995; Gooday, 2003; Van 
324 Hinsbergen et al., 2005), and benthic abundance is also often inversely correlated with water depth (e.g., 325 Murray, 1976; Culver, 1988; Van der Zwaan et al., 1990; Leckie and Olson, 2003). The seafloor at Site 326 M0077 was clearly well-oxygenated throughout the study interval as evidenced by abundant ichnofauna 327 (Morgan et al., 2017; Rodriguez Tovar et al., in press) due to the lack of a crater wall to the northeast 328 (Gulick et al., 2008). The site was located in upper/middle bathyal depths (600-700 m; Gulick et al., 2008; 329 Lowery et al., 2018), and low-amplitude sea level change throughout the early Paleocene (e.g., Miller et 330 al., 2020) should not have affected the \%benthics at this depth. With changes in oxygen and sea level thus 331 ruled out, we are confident that food supply to the seafloor (i.e., export production) was the strongest 332 influence on \%benthics at Site M0077. \%Benthics may reflect changes in either the quantity or the quality 333 (i.e., labile vs. refractory) of the organic matter that reached the seafloor (e.g., Jorissen et al., 1995). Export productivity, measured by $\mathrm{Ba} / \mathrm{Ti}$, was high overall in the early Danian, and broadly declined from 66.0 to $\sim 64.5 \mathrm{Ma}$ (616.5 to $\sim 613.7 \mathrm{mbsf}$ ) (Figure 6). The interval of highest export productivity terminated sharply around $65.7 \mathrm{Ma}(616.2 \mathrm{mbsf})$. The subsequent period of decline is interrupted by a second peak in export production which occurred around 65.2 Ma (615.1 mbsf), after which export production flattens out. The initial $\sim 1$ Myr period of high, generally declining export productivity is also reflected in the foraminifera populations. Benthic foraminifera are more abundant 340 overall in the early Danian (Figure 6), indicating either higher export of organic matter to the seafloor 341 overall or a relatively large proportion of labile organic matter being exported. Likewise, non-spinose, 342 non-symbiont-bearing planktic foraminifera are more abundant in the early Danian as well (Figure 6). 343 This dominance is not an artifact of post-extinction communities being composed of only non-spinose 344 foraminifera. Spinose foraminifera appeared essentially immediately after the extinction: the lowest 345 occurrences of Eoglobigerina and Parasubbotina occurs in Zone P0, while that of Subbotina occurs early 346 in Zone P1a, 300 kyr after the boundary, indicating that an evolutionary advantage conferred by spines 347 existed in at least some parts of the ocean soon after the impact. The fact that the multiple existing species of spinose foraminifera in the Chicxulub crater were out-competed by non-spinose foraminifera suggests 
that spines did not confer much of an advantage at this particular place and time, which indicates food must have been plentiful. Although not directly correlated with export productivity as measured by $\mathrm{Ba} / \mathrm{Ti}$, these foraminifer proxies provide additional context on the state of different aspects of the biological

352 pump. Calcareous nannoplankton abundance data (Figure 6) show that the interval of overall high

353 productivity was dominated by calcareous nannofossil "disaster taxa" which bloomed in the aftermath of 354 the K-Pg mass extinction (Jones et al., 2019). These taxa persist longer at Chicxulub ( 1 myr) than any 355 of the other sites.

The rest of the study interval is characterized by low and stable $\mathrm{Ba} / \mathrm{Ti}$ ratios (with several small

357 short-lived increases), higher abundances of oligotrophic planktic foraminifera, and fewer benthic 358 foraminifera. As export productivity entered the last stages of its decline, the calcareous nannoplankton 359 assemblage becomes more diverse, with the onset of a series of acme events, dominated by increasingly 360 oligotrophic taxa (Jones et al., 2019).

\section{Paleoceanographic evolution of the Chicxulub Crater}

Collectively, our data indicate a shift from high export productivity and weak stratification in the earliest Paleocene to low export productivity and strong stratification a few million years later. The change between these two regimes also marks a shift in the plankton community. This progression occurs in several steps (see numbered, shaded bars on Figure 6) detailed below.

\subsection{High export productivity, well-mixed water column (66.0-65.9 Ma).}

The first $100 \mathrm{kyr}$ after the Chicxulub impact (616.5-616.4 mbsf) were characterized by high export production and were dominated by mixed-layer planktic foraminifera, predominantly Guembelitria, Globoconusa, and Parvularugoglobigerina, while the disaster taxon Cervisiella dominated the nannoplankton community. Schaefer et al. (2020) used biomarkers to document a bloom of cyanobacteria in this interval as well. Several acmes of planktic foraminifera occurred across the Tethys and North Atlantic after that K-Pg boundary, termed Planktic Foraminiferal Acme Stages (PFAS; 
Arenillas et al., 2000, 2006, 2016; Alegret et al., 2004). These represent a coeval succession of dominant taxa in open marine sections over a wide geographic area. PFAS-1, the predominance of Guembelitria, occurs in this earliest interval of post-impact sedimentary rocks (Figure 7).

\subsection{Very High export productivity, increasing stratification (65.9-65.7 Ma).}

During the period from 100-320 kyr after the impact (616.4-616.1 mbsf), export productivity peaked, benthic foraminifer abundance increased, and thermocline and sub-thermocline dwelling foraminifera (Eoglobigerina and Chiloguembelina) became more common. This transition is coincident with a small increase in terrigenous flux (Figure 4). PFAS-2, the predominance of Globoconusa and Parvularugoglobigerina, occurs in this interval (Figure 7). The nannoplankton assemblage was still dominated by the calcareous resting cysts of dinoflagellates (Cervisiella).

\subsection{Declining export productivity, well stratified water column (65.7-65.6 Ma).}

A sharp decrease in export productivity occurred $\sim 320 \mathrm{kyr}$ after the boundary $(616.1 \mathrm{mbsf})$ in the middle of a period of well-developed water column stratification. Braarudosphaera became predominant in the nannofossil assemblage as Cervisiella declined, but this is coincident with an increase in foraminifer-sized calcispheres tentatively identified as Cervisiella (Figure 6), suggesting that this taxon may have just grown to a larger size because of a shift to particularly suitable conditions. Lieberand et al. (2017) found Braarudosphaera oozes associated with hyperstratification during during the Oligocene.

This matches with increase in stratification we observe with planktic foraminifera at Site M0077. PFAS3, the predominance of Woodringina and the sub-thermocline-dwelling Chiloguembelina, also begins in this interval. This correlation, and the brief nature of this event, suggests that the changes in stratification observed at Site M0077 are part of larger trends that extend at least across the North Atlantic. The DanC2 hyperthermal, which is not recorded in our carbon isotope data but which occurred at $65.7 \mathrm{Ma}$ across the North Atlantic (e.g., Quillévéré et al., 2008; Barnet et al., 2019), may have caused an increase in thermal stratification. A reduction in latitudinal temperature gradients during warm periods could have 
reduced circulation and increased stratification. The lack of the diagnostic isotope excursion for this event at Site M0077 may be due to a combination of low sedimentation rate and pervasive bioturbation combined with diagenetic alteration of the carbonate; there is no evidence for a hiatus at this level. This interval is not associated with any evidence for increased terrigenous flux.

4.4 Moderate export productivity, poorly stratified water column (65.6-65.1 Ma). again dominated the planktic foraminiferal assemblage. Benthic foraminifera reached their peak abundance, perhaps indicating an increase in labile organic matter arriving at the seafloor. Foraminifersized calcispheres peaked and then declined as Cervisiella again came to dominate the nannofossil assemblage (Jones et al., 2019). Export productivity had declined from its earlier peak but was still

407 relatively elevated compared to subsequent values.

4.5 Stratification redevelops and productivity bottoms out (65.1-64.7 Ma)

Over the next $\sim 400 \mathrm{kyr}(614.9-614.1 \mathrm{mbsf})$ stratification gradually strengthened while export productivity slowly declined following a final large peak just below this interval. The termination of this

411 peak is associated with the onset of the first bloom of incoming Paleocene nannoplankton, Futuyania 412 petalosa, at the very base of this interval, $900 \mathrm{kyr}$ after the K-Pg boundary (Jones et al., 2019). This taxon 413 becomes more abundant throughout this interval, in conjunction with a small peak in the $\mathrm{Ba} / \mathrm{Ti}$ ratios 414 indicating export production that was lower than before but still higher than what is to come. Declining 415 export productivity is associated with an increase in spinose foraminifera, which have a broader diet than 416 non-spinose, non-symbiont-bearing planktics and thus were (and still are) better suited for lower nutrient 417 waters (e.g., Hemleben et al., 1991).

Total organic carbon is essentially zero for the first million years of the Danian and is higher, 419 although still low, from 65.0-62.5 Ma (Figure 6). TOC enrichment is controlled by both productivity and preservation (e.g., Pederson and Calvert, 1990), so an increase in TOC concurrent with a reduction in 
421 export productivity suggests an increase in the preservation potential of organic matter. The most likely

422 mechanism for this increase is reduced ventilation of the seafloor, suggesting enhanced stratification at

423 the study area after 65.0 Ma. Biomarker data indicate the development of intermittent photic zone euxinia

424 in the crater at this time, providing additional evidence for increased stratification (Schaefer et al., 2020).

425 This interval is concurrent with increasing terrigenous flux (Figure 5).

4.6 Stable, Stratified Water Column, Low Export Productivity (64.7-62.6 Ma) stacked unconformities spanning the uppermost Danian to the PETM, documents a stable, stratified,

429 increasingly oligotrophic environment. A stepped decline in $\mathrm{Ba} / \mathrm{Ti}$ at the base of this interval is associated 430 with the initiation of the acme of Cruciplacolithus primus and then Coccolithus pelagicus (Jones et al., 431 2019). Following the Praeprinsius acme, which terminates around $63.5 \mathrm{Ma}$ (Jones et al., 2019), no further 432 acmes occur, indicating that the post-extinction ecosystem was finally stabilized. Ba/Ti ratios are 433 essentially stable although increase slightly through this interval.

5 What Drove the Decline in Export Production?

A clear change in export productivity occurs $\sim 300$ kyr after the K-Pg boundary at many sites 436 around the globe, although with local differences in whether export production goes up or down. In the 437 western Gulf of Mexico, benthic foraminiferal assemblages indicate an increase to pre-extinction levels of 438 export production $\sim 300$ kyr post impact (Alegret et al., 2001; Alegret and Thomas, 2005). Benthic

439 foraminifer assemblages document a similar increase $~ 300 \mathrm{kyr}$ after the K-Pg boundary on the eastern 440 side of the Atlantic Ocean in Spain (Alegret and Thomas, 2005). At the Gubbio section in Italy there is an 441 increase in benthic foraminifer abundance around $300 \mathrm{kyr}$ after the boundary, suggesting higher export 442 productivity (Coccioni et al., 2010). At Maud Rise in the Southern Ocean, Ba/Ti and Ba/Fe ratios begin to 443 rise $\sim 300$ kyr after the K-Pg boundary (Hull and Norris, 2011). At Shatsky Rise in the equatorial Pacific, 444 export productivity briefly increases $~ 300 \mathrm{kyr}$ after the K-Pg (Hull and Norris, 2011). Birch et al. (2016) 
found an initial recovery of export productivity $~ 300 \mathrm{kyr}$ after the boundary at Walvis Ridge in the South

446 Atlantic. These sites are broadly distributed geographically, and represent a range of depositional

447 environments. Although there are other sites at which no change is observed at this point in time (e.g.,

448 Vigo Seamount, São Paulo Plateau, and Wombat Plateau; Hull and Norris, 2011), the lack of a globally

449 consistent shift in productivity may be considered analogous to other major paleoceanographic events,

450 like the Paleocene Eocene Thermal Maximum (e.g., Gibbs et al., 2006) or Oceanic Anoxic Event 2

451 (Tsikos et al., 2004), in which local signals often differ significantly from the global "average" change.

These widespread shifts in export productivity around 65.7 Ma could be driven by a shift in ocean

circulation patterns driving a shift in thermal stratification and mixing processes which reduced nutrient delivery to the euphotic zone. Indeed, there are limited data in support of changes in stratification at this time, including at Walvis Ridge in the South Atlantic (Birch et al., 2016) and the Gubbio section in Italy (Coccioni et al., 2010).

An alternative explanation is that shifts in export production are part of the gradual recovery of marine ecosystems after a major mass extinction event. In this hypothesis, changes in the plankton ecosystem drove changes in the local biological pump and explain regional patterns of export productivity 460 change. Plankton ecology is the single most important control on the strength and efficiency of the biological pump (e.g., Henson, 2012). In the modern ocean, net primary production (NPP) driven by large celled phytoplankton like diatoms and coccolithophores results in a stronger biological pump and thus higher export production (e.g., Boyd and Newton, 1995, 1999; Buessler, 1998; Legrende and Rivkin, 2002; Boyd and Trull, 2007; Lam et al., 2011; Boyd, 2015). Primary production by smaller-celled picophytoplankton like algae and cyanobacteria sinks more slowly and is more easily remineralized in surface waters (the "microbial loop"); in regions where picoplankton dominate primary production,

467 nutrients are constantly recycled at shallow depth and export production is primarily composed of more refractory organic matter which is resistant to degradation (Legrendre and Michaud, 1998; de la Rocha and Passow, 2007). Counter intuitively, even though the biological pump is weaker when primary 
production is dominated by picoplankton (less organic matter is exported from the euphotic zone), it is

471 more efficient (a larger proportion of the organic matter that is exported from the euphotic zone safely

472 sinks to the seafloor because it is more refractory). This is because even though larger celled

473 phytoplankton tend to sink more quickly, they don't sink quickly enough to avoid scavenging at

474 intermediate depths, so the abundance of larger phytoplankton has the net effect of removing organic

475 matter and nutrients from the euphotic zone but not exporting it efficiently to the seafloor. For example,

476 Henson et al. (2012) document a strong, inefficient biological pump at high latitudes driven by diatoms,

477 in which 15-25\% of NPP sinks below the euphotic zone but only 1-10\% of that material reaches $2000 \mathrm{~m}$

478 water depth (where it is considered "exported," i.e., removed from the short term carbon cycle). On the

479 other hand, they describe a weak, efficient pump at low latitudes driven by small-celled phytoplankton, where only $1-5 \%$ of NPP makes it out of the euphotic zone but $20-35 \%$ of that makes it to $2000 \mathrm{~m}$.

After the K-Pg mass extinction, the dominant larger-celled phytoplankton of the Cretaceous, calcareous nannoplankton, declined severely. Primary production was carried on by picoplankton like chlorophyte algae (Sepúlveda et al., 2009) and cyanobacteria (Schaefer et al., 2020; Bralower et al., in revision), weakening the biological pump. In some oligotrophic regions, the shift toward picoplankton and enhanced recycling of nutrients in the euphotic zone may have actually driven a local increase in 486 primary productivity (see discussion in Henehan et al., 2019). If the southern Gulf of Mexico was one of 487 these regions, then the recovery of calcareous nannoplankton would have facilitated a higher removal of 488 nutrients from the euphotic zone, thus causing the observed local shift from eutrophic to oligotrophic 489 conditions.

Thus we have two hypotheses to explain the early Paleocene export productivity data at Site

491 M0077: 1) increasing stratification (driven either by changes in global circulation or the local hydrologic cycle) reducing nutrient availability, or 2) a recovery of larger celled phytoplankton increasing export of nutrients and organic matter from the euphotic zone, reducing nutrient availability. Testing the latter hypothesis would require data on the relative abundance of groups of phytoplankton which do not usually 
leave body fossils, like algae and cyanobacteria, and such data does not currently exist for any K-Pg boundary section. Biomarker data from the Chicxulub crater do indicate a dominance of cyanobacteria in

497 the first few 100 kyrs after the K-Pg Boundary (Schaefer et al., 2020), corresponding to the interval of the 498 highest export production and thus providing some support for this idea. Bralower et al. (in revision)

499 found evidence of global blooms of microbial phytoplankton associated with the widespread deposition of 500 microcrystalline calcite above the K-Pg boundary. Moreover, Alvarez et al. (2019) found an increase in 501 average nannoplankton cell size coincident with the initial increase in diversity at Shatsky Rise in the 502 503 504 505 506 productivity in the Chicxulub crater.

Figure 8 is a series of cross plots showing the lack of correlation between export productivity indicated by $\mathrm{Ba} / \mathrm{Ti}$ ratios and proxies for stratification and terrigenous flux. Figures $8 \mathrm{~A}$ and $\mathrm{B}$ compare two proxies for overall terrestrial input, total Fe and magnetic susceptibility, with export productivity;

511 both clearly show no trend. Figure $8 \mathrm{C}$ compares the ratio of Ti to $\mathrm{Al}$, which tracks shifts in aeolian vs. 512 riverine input (e.g., Govin et al., 2012) with export productivity. There are clear shifts in the Ti/Al ratio 513 (Figure 4) coincident with shifts in $\mathrm{Ca}$ and $\mathrm{Fe}$, indicating that shifts between wetter and drier climate 514 states drove changes in the delivery of terrigenous elements to Site M0077. However, when plotted 515 against $\mathrm{Ba} / \mathrm{Ti}$, it is clear that such shifts in sediment source have no bearing on export productivity. But 516 perhaps nutrients were sourced from depth, and there is a relationship between a weakly stratified water 517 column (facilitating upwelling) and enhanced export production. Figure 8D compares the percentage of 518 mixed layer planktic foraminifera with $\mathrm{Ba} / \mathrm{Ti}$ to test this idea, and convincingly demonstrates that changing stratification was unrelated to export productivity. 
We therefore conclude that changes in terrigenous flux and stratification did not affect early

521 Paleocene export productivity in the southern Gulf of Mexico. We favor the hypothesis that turnover in

522 phytoplankton communities from picophytoplankton like cyanobacteria to larger phytoplankton like

523 coccolithophores drove a strengthening of the biological pump and, paradoxically, a reduction in the

524 nutrients in the photic zone and thus a decline in export production. Biomarker-based studies of the whole

525 plankton ecosystem from multiple early Paleocene sites are necessary to test this hypothesis.

526

527

528

529

530

531

532

533

534

535

536

537

538

539

540

541

542

543

\section{Conclusions}

The earliest Danian oceanic environment is often referred to as generally "unstable" (e.g., Hull et al., 2011). Our data suggest that at least one component of this instability is a fluctuating degree of water column stratification. Water column stratification varied widely over the first $\sim$ million years of the

Paleocene, but with an overall trend from poorly stratified to well stratified. Export productivity varied over the same interval, with an overall decreasing trend. There is no strong correlation between proxies for stratification or terrigenous flux with export productivity. Instead, we suggest that the decline in export productivity was linked to turnover in the phytoplankton community, as post-impact blooms of cyanobacteria (Schaefer et al., 2020; Bralower et al., in revision) and other non-fossilizing picophytoplankton gave way to larger calcareous nannoplankton. Picophytoplankton sink so slowly that they are generally completely remineralized in the euphotic zone, increasing nutrients there and ensuring that most organic export was highly refractory and thus likely to survive its trip to the seafloor. Larger celled phytoplankton sink more quickly, and thus remove more nutrients from the euphotic zone. However, this sinking is not fast enough to avoid scavenging below the euphotic zone, and the more labile organic matter is more easily remineralized as it sinks, resulting in lower overall export of organic carbon to the seafloor in regions not predisposed to high productivity. Existing data from Site M0077 support this plankton ecology hypothesis, with a dominance of cyanobacteria during the interval of highest export production, and recovery of calcareous nannoplankton diversity as export production 
544 declines, but more complete biomarker data on the rest of the non-fossilizing phytoplankton ecosystem

545 are required to truly test it.

546

547 Data Availability Statement

548 Planktic foraminifer data and XRF core scan data will be uploaded to the NOAA National Climate Data

549 Center before publication. Calcareous nannoplankton data are from Jones et al. (2019) and are archived as

$550 \quad$ GSA Data Repository Item 2019271.

551

552 Acknowledgements

553 We are grateful to Ellen Thomas, Julio Sepúlveda, and two anonymous reviewers for their constructive 554 comments, which have substantially improved this work. The authors acknowledge NSF OCE 1737351, 555 1736951, and 1737199. We are grateful to Pincelli Hull for her helpful discussions on our data and hers, 556 and to the staff of the Bremen Core Repository for their invaluable help sampling and scanning the core. 557 We also thank Tessa Cayton for her assistance preparing foraminifer samples. I.A. and J.A.A. acknowledge 558 the use of the Servicio General de Apoyo a la Investigación-SAI, Universidad de Zaragoza. The European 559 Consortium for Ocean Research Drilling (ECORD) implemented Expedition 364 with funding from the 560 International Ocean Discovery Program (IODP) and the International Continental scientific Drilling Project 561 (ICDP). Data and samples can be requested from IODP. U.S. participants in Exp. 364 were supported by 562 the U.S. Science Support Program. J.V.M. was funded by NERC, Grant: NE/P005217/1. I.A. and J.A.A. 563 were supported by MINECO/FEDER-UE (project number CGL2015-64422-P) and MCIU/AEI/FEDER, 564 UE (project number PGC2018-093890-B-I00). This is UTIG Contribution \#3661. 
567 Expedition 364 Science Party: Elise Chenot, Gail Christeson, Philippe Claeys, Charles

568 Cockell, Marco J. L. Coolen, Ludovic Ferrière, Catalina Gebhardt, Kazuhisa Goto, Sophie

569 Green, Kliti Grice, Sean Gulick, Heather Jones, David A. Kring, Johanna Lofi, Christopher M.

570 Lowery, Claire Mellett, Joanna Morgan, Rubén Ocampo-Torres, Ligia Perez-Cruz, Annemarie

571 Pickersgill, Michael Poelchau, Auriol Rae, Cornelia Rasmussen, Mario Rebolledo-Vieyra, Ulrich

572 Riller, Honami Sato, Bettina Schaefer, Jan Smit, Sonia Tikoo, Naotaka Tomioka, Jaime Urrutia-

573 Fucugauchi, Michael Whalen, Axel Wittmann, Long Xiao, Kosei Yamaguchi, William

574 Zylberman

575

576 Table 1. Biostratigraphic datums for the Paleocene interval of Hole M0077A. Nannofossil datums

577 marked with asterisks are not used in the age model. Datum ages after Gradstein et al. (2012).

\begin{tabular}{llrrrr}
\hline \multirow{2}{*}{ Taxon } & Zone & $\begin{array}{c}\text { Sample } \\
\text { Above }\end{array}$ & $\begin{array}{c}\text { Sample } \\
\text { Below }\end{array}$ & $\begin{array}{c}\text { Avg. } \\
\text { Depth }\end{array}$ & $\begin{array}{c}\text { Datum } \\
\text { Age }\end{array}$ \\
\hline Discoaster multiradiatus & Base of CP8 & 607.26 & 607.37 & $\mathbf{6 0 7 . 3 1 5}$ & $\mathbf{5 7 . 2 1}$ \\
Morozovella acuta & Base of P4b & 607.52 & 607.76 & $\mathbf{6 0 7 . 6 5}$ & $\mathbf{5 7 . 7 9}$ \\
Heliolithus kleinpellii* & Base of CP5 & 607.52 & 607.76 & $\mathbf{6 0 7 . 6 5}$ & $\mathbf{5 9 . 9 4}$ \\
Igorina pusilla & Base of P3a & 609.28 & 609.3 & $\mathbf{6 0 9 . 2 9}$ & $\mathbf{6 2 . 3}$ \\
Praemurica uncinata & Base of P2 & 610.6 & 610.65 & $\mathbf{6 1 0 . 6 3}$ & $\mathbf{6 2 . 6}$ \\
Globanomalina compressa & Base of P1c & 612.36 & 612.41 & $\mathbf{6 1 2 . 3 8 5}$ & $\mathbf{6 3 . 9}$ \\
Chiasmolithus danicus* & Base of CP2 & 612.5 & 612.75 & $\mathbf{6 1 2 . 6 2 5}$ & $\mathbf{6 4 . 8 1}$ \\
Subbotina triloculinoides & Base of P1b & 615.21 & 615.26 & $\mathbf{6 1 5 . 2 3 5}$ & $\mathbf{6 5 . 2 5}$ \\
Parvularugoglobigerina eugubina & Base of P1a & 616.15 & 616.2 & $\mathbf{6 1 6 . 1 7 5}$ & $\mathbf{6 5 . 7 2}$ \\
Parvularugoglobigerina eugubina & Base Pa & 616.56 & 616.56 & $\mathbf{6 1 6 . 5 6}$ & $\mathbf{6 6}$ \\
\hline
\end{tabular}




\begin{tabular}{|c|c|c|c|}
\hline $\begin{array}{c}\text { Aze et al. } 2011 \\
\text { ecogroups }\end{array}$ & Group & Explanation & Members \\
\hline Group 1 & $\begin{array}{l}\text { Open ocean mixed-layer } \\
\text { tropical/subtropical, with } \\
\text { symbionts }\end{array}$ & $\begin{array}{l}\text { Very heavy } \delta^{13} \mathrm{C} \text { and relatively light } \\
\qquad \delta^{18} \mathrm{O}\end{array}$ & $\begin{array}{r}\text { Morozovella, Igorina, Acarinina, Praemurica } \\
\text { inconstans }{ }^{\sim} \text {, Preamurica pseudoinconstans }, \\
\text { Praemurica uncinata } ~\end{array}$ \\
\hline Group 2 & $\begin{array}{c}\text { Open Ocean mixed-layer } \\
\text { tropical/subtropical, without } \\
\text { symbionts }\end{array}$ & $\begin{array}{c}\delta^{13} \mathrm{C} \text { lighter than species with } \\
\text { symbionts; also relatively light } \\
\delta^{18} \mathrm{O}\end{array}$ & $\begin{array}{r}\text { Guembelitria*, Parvularugoglobigerina*, } \\
\text { Woodringina*, Globoconusa daubjergensis*+, } \\
\text { Rectuvigerina cretacea*, Praemurica taurica, } \\
\text { Subbotina triangularis, }\end{array}$ \\
\hline Group 3 & Open Ocean thermocline & $\begin{array}{l}\text { Light } \delta^{13} \mathrm{C} \text { and relatively heavy } \\
\qquad \delta^{18} \mathrm{O}\end{array}$ & $\begin{array}{r}\text { Globanomalina, Eoglobogerina Parasubbotina } \\
\text { varianta, Subbotina trivialis, Subbotina } \\
\text { triloculinoides }\end{array}$ \\
\hline Group 4 & Open Ocean sub-thermocline & Very light $\delta^{13} \mathrm{C}$ and very heavy $\delta^{18} \mathrm{O}$ & $\begin{array}{r}\text { Chiloguembelina midwayensis*, Chiloguembelina } \\
\text { morsei^, P. pseudobulloides }\end{array}$ \\
\hline Group 5 & High Latitude & $\begin{array}{l}\text { Species only found in high latitude } \\
\text { sites }\end{array}$ & $\mathrm{N} / \mathrm{A}$ \\
\hline Group 6 & Upwelling/high productivity & $\begin{array}{l}\text { Species only found in sites of high } \\
\text { productivity or upwelling }\end{array}$ & $\mathrm{N} / \mathrm{A}$ \\
\hline
\end{tabular}

*Olsson et al., 1999 and references therein

+Olsson (1999): "Although its abundance in near-shore sequences indicates a near-surface planktic habitat (Troelsen, 1957; Keller, 1989; Liu and Olsson, 1992), its oxygen isotopic signature and open-marine abundance patterns suggest a preference for relatively cool water masses (Premoli Silva and Boersma, 1989; D'Hondt and Keller, 1991; Liu and Olsson, 1992; D'Hondt and Zachos, 1993)."

$\sim$ Norris (1996) and Birch et al. (2012) describe P. inconstans, P. pseudoinconstans, and P. uncinata, as symbiont-bearing.

${ }^{\wedge}$ no isotope data are available for any other Paleocene Chiloguembelinids, so we place $C h$. morsei in this group based on the data from its cousin Ch. midwayensis. 


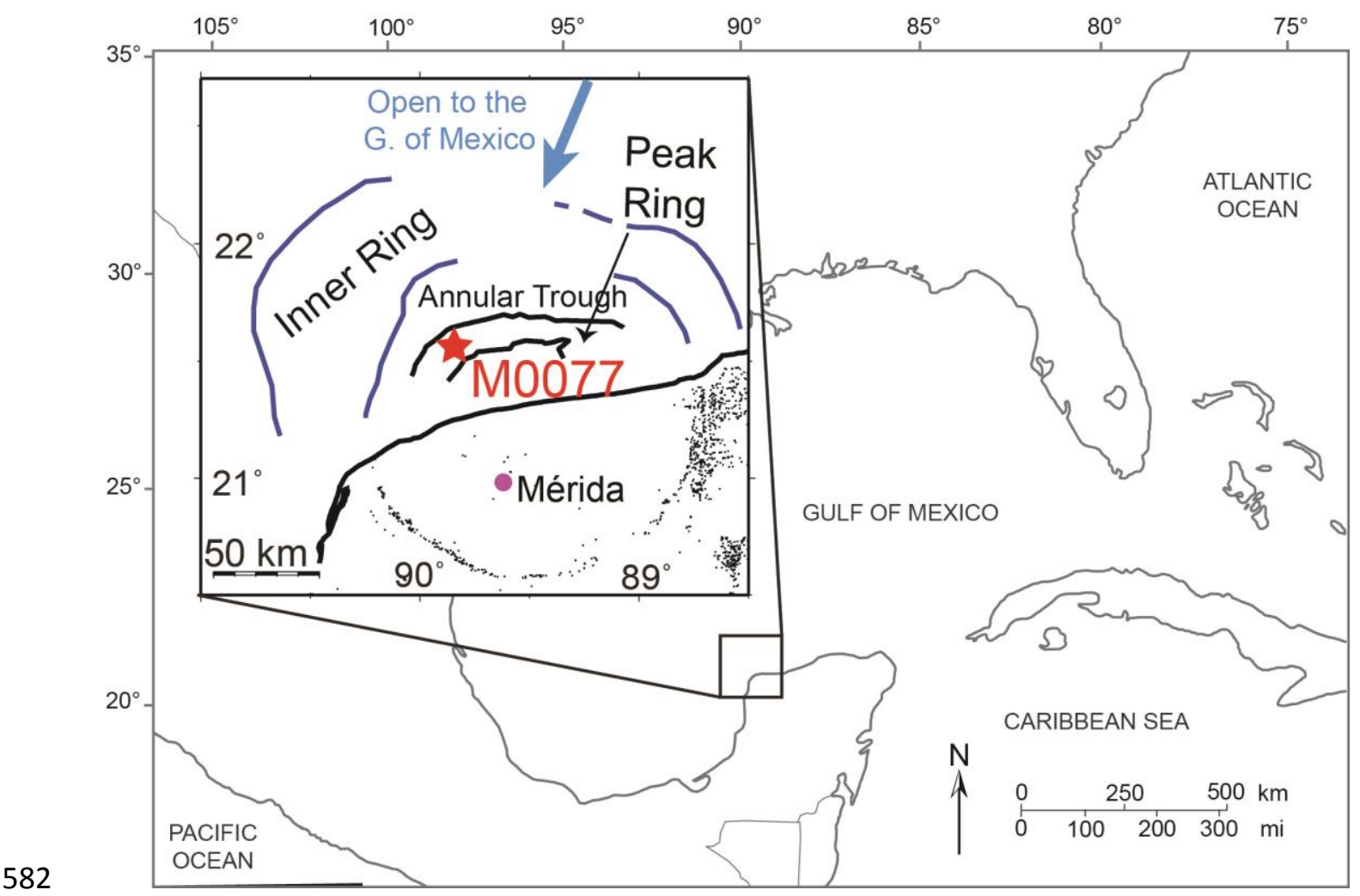

583 Figure 1. Location map showing the position of IODP Site M0077 within the Chicxulub crater.

584

585

586 


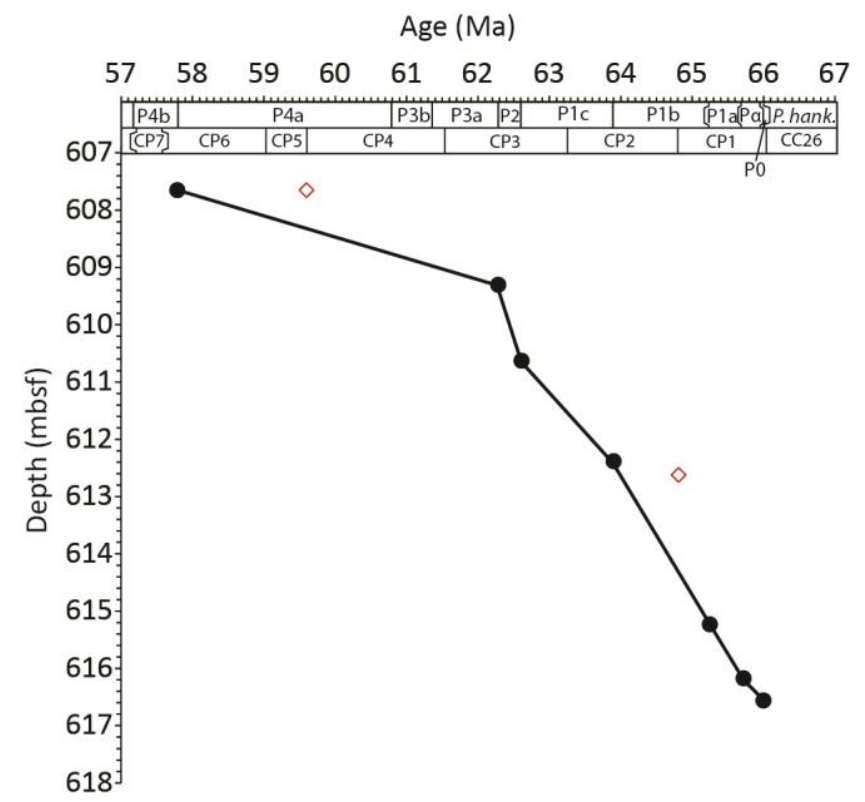

588 Figure 2. Age-Depth plot showing the construction of the age model. Black circles are planktic

589 foraminifer datums, open diamonds are calcareous nannoplankton, several of which are missing from this 590 core. P zones are planktic foraminifer and CP zones are calcareous nannoplankton. The study focuses on 591 the first $\sim 3.5$ myr of the Paleocene, to the base of Zone P2. 


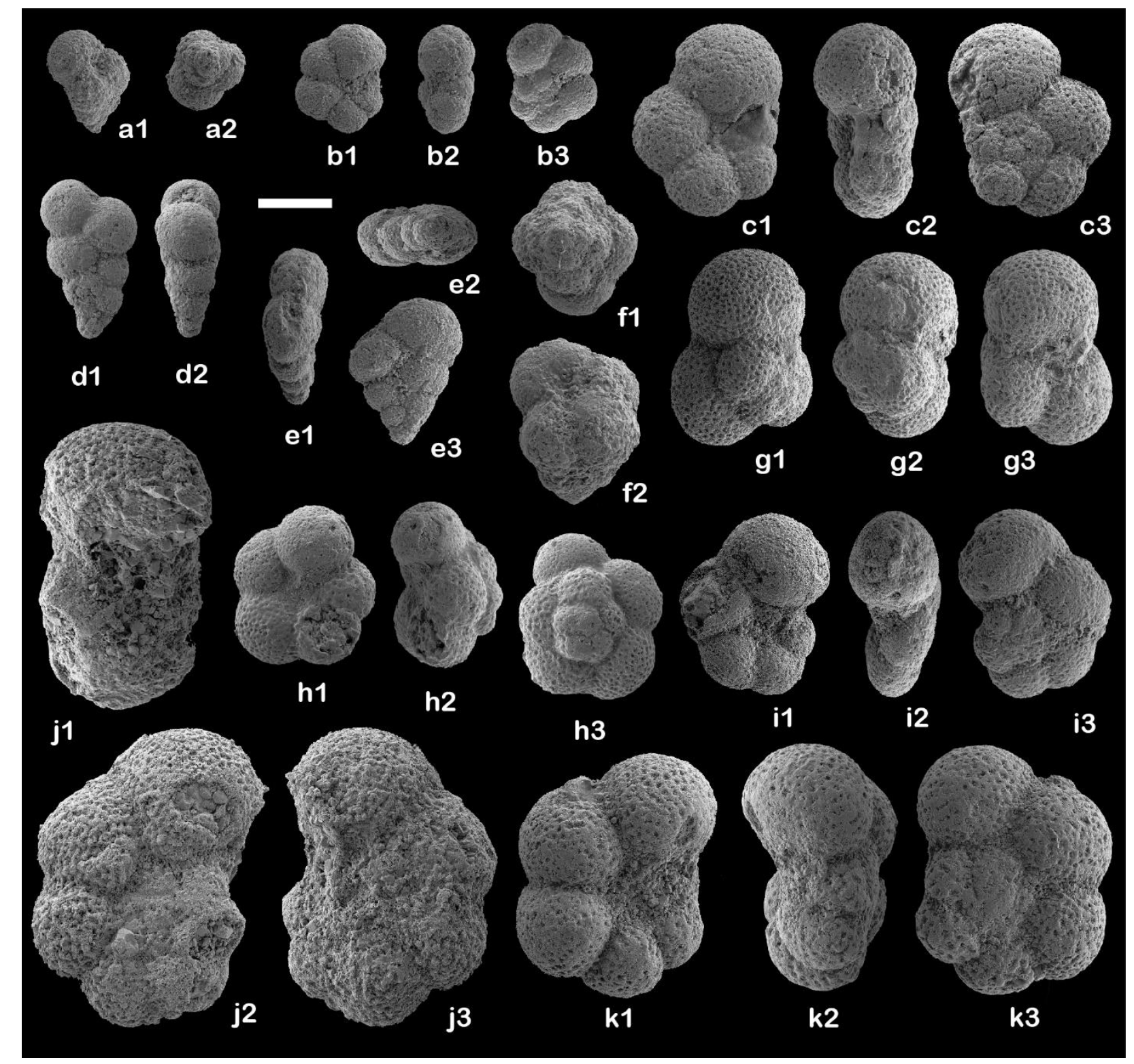

593 Figure 3. SEM images of planktic foraminiferal index-species and other relevant species (scale bar $=100$

594 microns). (a) Guembelitria cretacea (364-M0077A-39R-2 85-86 cm); (b) Parvularugoglobigerina

595 eugubina (364-M077A-40R-1 17-18 cm); (c) Parasubbotina pseudobulloides (364-M0077A-39R-1 128-

$596129 \mathrm{~cm}) ; \quad$ (d) Chiloguembelina morsei (364-M0077A-39R-2 98-99 cm); (e) Chiloguembelina

597 midwayensis (364-M0077A-39R-3 41-42 cm); (f) Globoconusa daubjergensis (364-M0077A-37R-2 116-

$598117 \mathrm{~cm})$; (g) Subbotina triloculinoides (364-M0077A-38R-2 60-61 cm); (h) Eoglobigerina edita (364-

599 M077A-38R-2 60-61 cm); (i) Globanomalina compressa $\quad$ (364-M0077A-37R-1 $116-117 \quad \mathrm{~cm})$; 
$601 \quad 37-38 \mathrm{~cm})$.
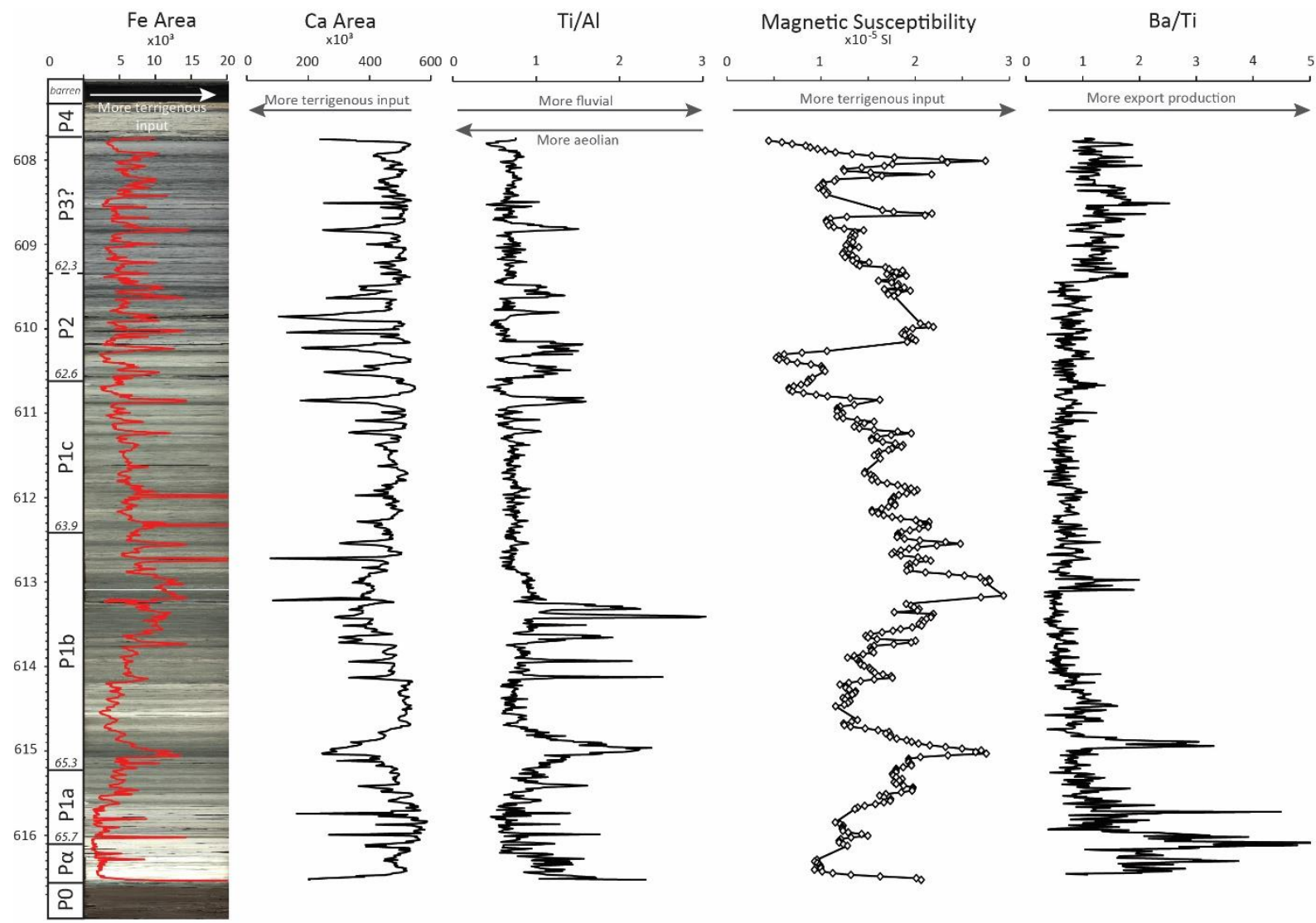

602

603 Figure 4. Sedimentological proxies vs. depth. Core linescan composite of the Paleocene interval at Site

604 M0077 is overlaid by XRF Fe counts. Increased Fe, decreased $\mathrm{Ca}$, increased Ti/Al, and higher magnetic 605 susceptibility are all proxies for higher terrigenous flux. Increased $\mathrm{Ba} / \mathrm{Ti}$ indicated higher local export 606 productivity. 


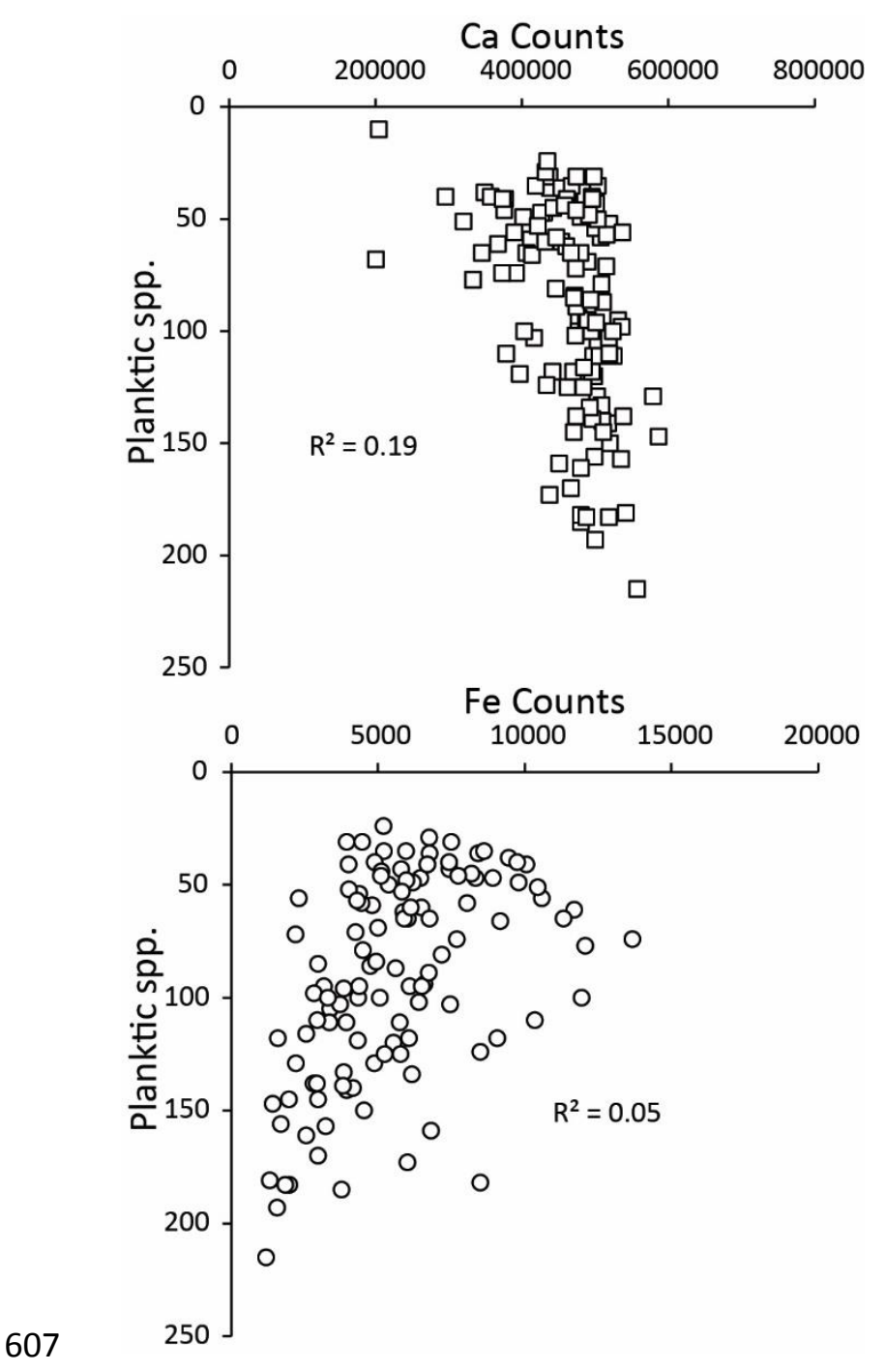

608 Figure 5. Preservation vs Calcium and Iron XRF counts. Better preservation is toward zero on the y-axis 609 (i.e., fewer unidentifiable foraminifera). Two outliers $>80,000$ from pyrite-rich samples at the base of the 610 section were removed from the Fe plot. Ca shows a weak negative correlation with good preservation while 611 Fe shows a weak positive correlation with good preservation. This pattern is the opposite of trends caused 612 by dissolution. 


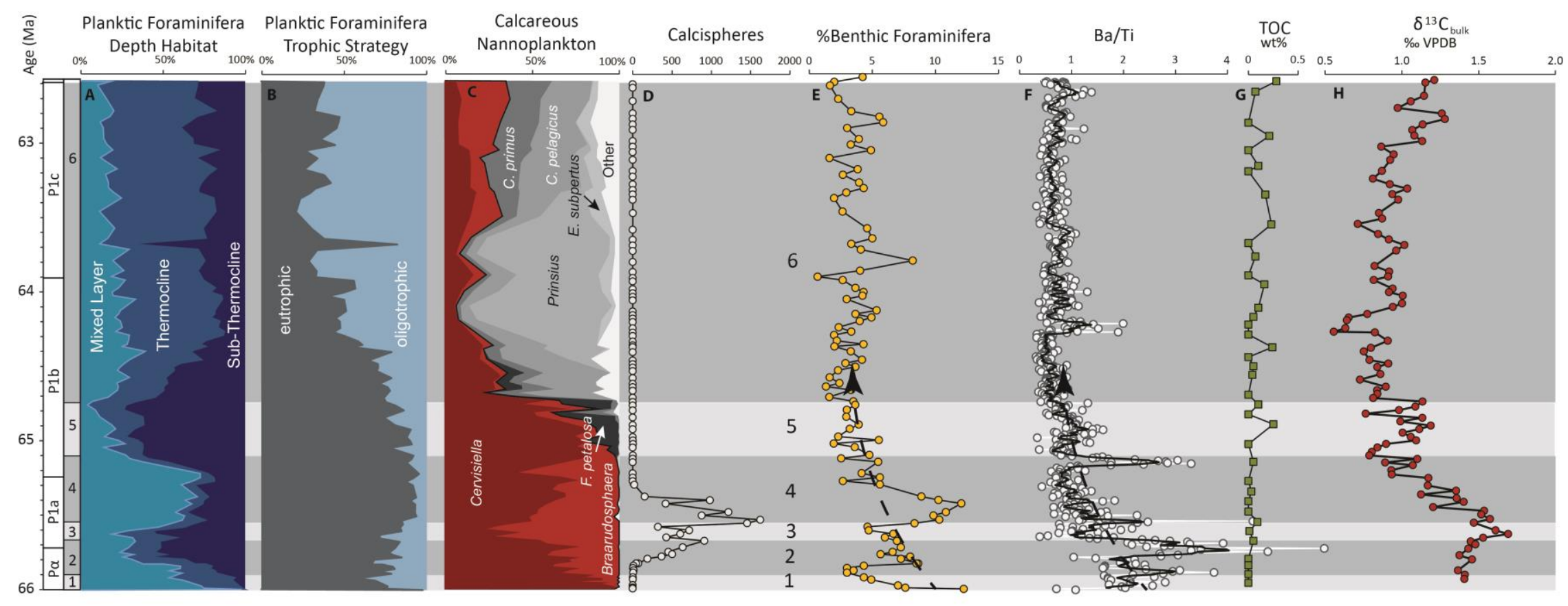

614 Figure 6. Paleoceanography proxies plotted by age. Planktic foraminifer by depth habitat record the stratification of the upper water column; see Table 2 for species assigned to mixed layer, thermocline, and subthermocline planktic foraminifer groups. Planktic foraminifera by trophic strategy record changes in paleoproductivity in the upper water column, Calcareous nannoplankton diversity shows the relative abundance of all (nonreworked) species of calcareous nannoplankton present; red taxa are the so called "disaster" opportunists, grey are incoming Paleocene taxa. Calcispheres shows the abundance of calcispheres $>45 \mu \mathrm{m}$. \%Benthics is the percentage of benthic foraminifera relative to all foraminifera, and is interpreted to correspond primarily to abundance and quality of nutrient flux to the seafloor. $\mathrm{Ba} / \mathrm{Ti}$ records paleoproductivity, with high ratios indicating high productivity. TOC (total organic carbon) corresponds to changes in preservation potential of organic carbon at the seafloor. Numbered gray bars represent discrete intervals discussed in Section 4 of the text. 


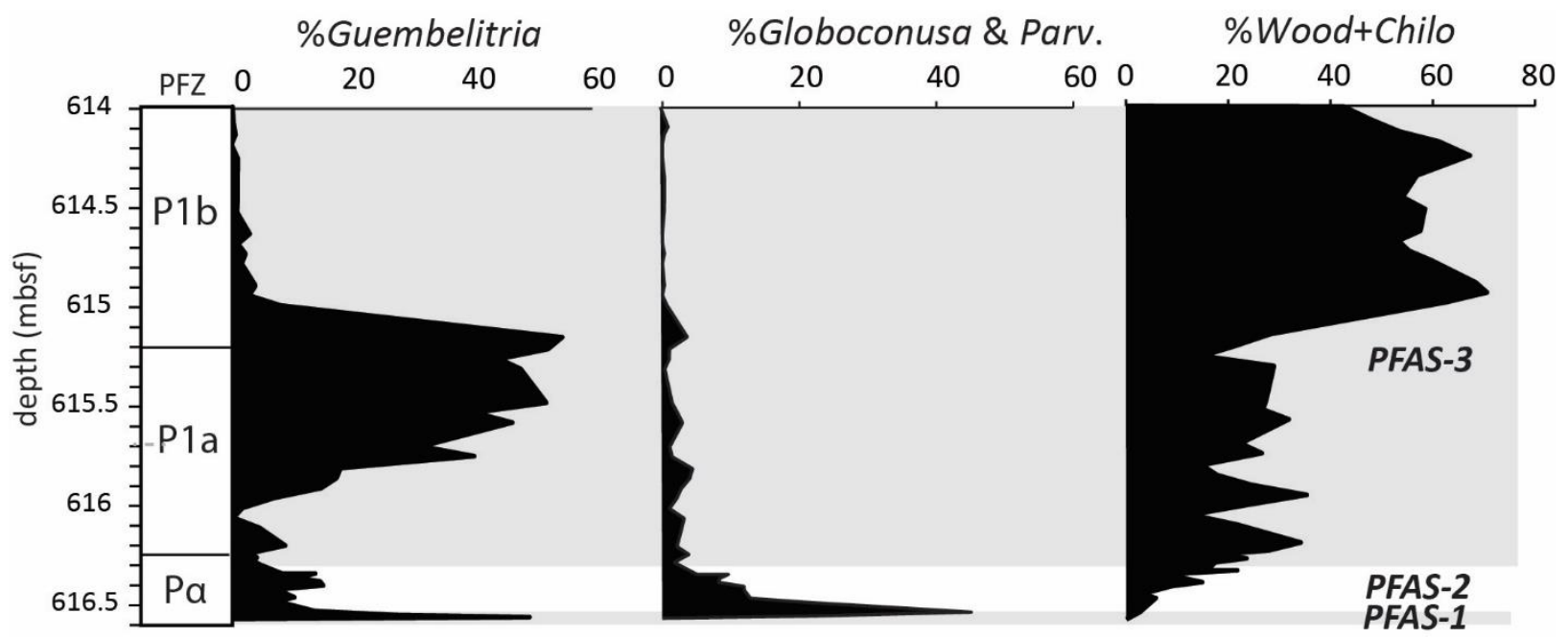

623 Figure 7. Quantitative stratigraphic distribution of early Danian planktic foraminiferal groups at Site

624 M0077 and Planktic Foraminiferal Acme Stages (PFAS) 1-3: PFAS-1 is the predominance of Guembelitria,

625 PFAS-2 is the predominance of Parvularugoglobigerina and Globoconusa (or Palaeoglobigerina 626 according to Arenillas and Arz, 2017), and PFAS-3 is the predominance of Woodringina and 627 Chiloguembelina. A second acme of Guembelitria (or Chiloguembelitria according to Arenillas and Arz, 628 2017) occurs within this stage across the Tethys, as is also evident at Site M0077. 

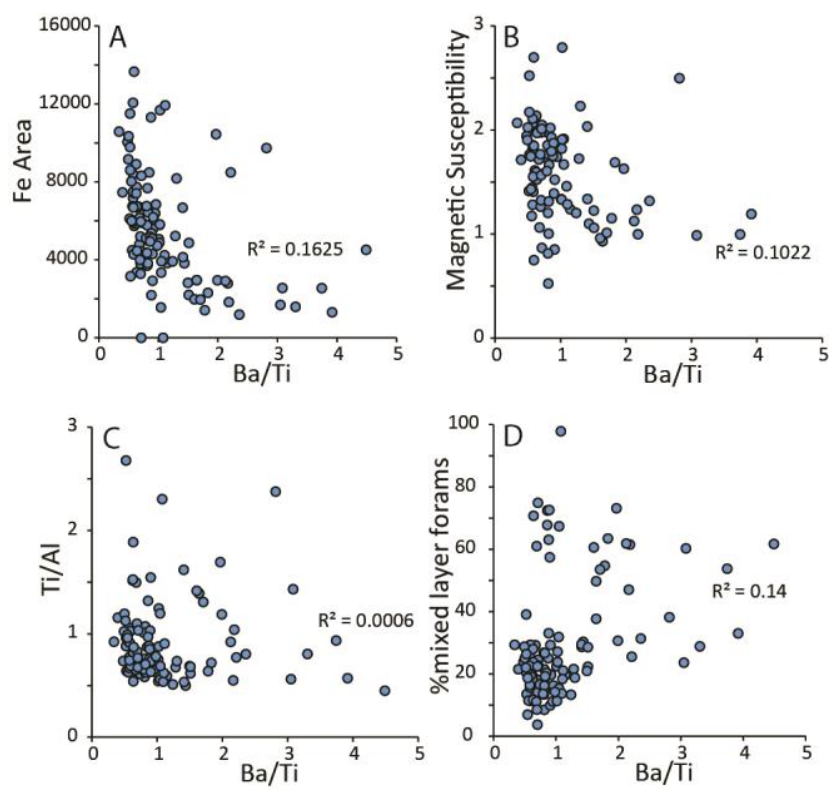

638 Figure 8. Cross plots of $\mathrm{Ba} / \mathrm{Ti}$ ratios (i.e., export productivity) with proxies for stratification and terrigenous

639 flux: A) XRF Fe counts, a proxy for sedimentary dilution by terrigenous sediments, B) magnetic 640 susceptibility, a proxy for the influx of terrigenous material, C) Ti/Al, a proxy for the relative abundance 641 of riverine (Ti) vs. aeolian (Al) flux, D) the percent abundance of mixed layer foraminifera vs. total 642 foraminifera, a proxy for the vertical stratification of the upper water column. $\mathrm{R}^{2}$ values (and your eyeballs, 643 probably) indicate that all 4 are uncorrelated and thus changes in export productivity were not related to 644 terrigenous flux of water column stratification. 
652

653

654

655

656

657

658

659

660

661

662

663

664

665

666

667

668

669

670

671

672

\section{REFERENCES}

Alegret, L., Molina, E., \& Thomas, E. (2001). Benthic foraminifera at the Cretaceous-Tertiary boundary around the Gulf of Mexico. Geology, 29, 891-894.

Alegret, L., \& Thomas, E. (2005). Cretaceous/Paleogene boundary bathyal paleo-environments in the central North Pacific (DSDP Site 465), the Northwestern Atlantic (ODP Site 1049), the Gulf of Mexico and the Tethys: The benthic foraminiferal record. Palaeogeography, Palaeoclimatology, Palaeoecology, 224, 53-82.

Alegret, L., Arenillas, I., Arz, J. A., \& Molina, E. (2004). Foraminiferal event-stratigraphy across the Cretaceous/Paleogene boundary. Neues Jahrbuch für Geologie und Paläontologie - Abhandlungen, 234, 25-50.

Alegret, L., E. Thomas, \& K.C. Lohmann (2012), End-Cretaceous marine mass extinction not caused by productivity collapse, Proceedings of the National Academy of Sciences, 109(3), 728-732.

Alvarez, L.W., Alvarez, W., Asaro, F., \& Michel, H.V., 1980. Extraterrestrial cause of the CretaceousTertiary extinction. Science 208, 1095-1108.

Arenillas, I., Arz, J. A., Molina, E., \& Dupuis, C. (2000). An independent test of planktic foraminiferal turnover across the Cretaceous/Paleogene (K/P) boundary at El Kef, Tunisia; catastrophic mass extinction and possible survivorship. Micropaleontology, 46, 31-49.

Arenillas, I., Arz, J.A., Grajales-Nishimura, J.M., Murillo-Muñetón, G., Alvarez, W., Camargo-Zanoguera, A., Molina, E., Rosales-Domínguez, C. (2006). Chicxulub impact event is Cretaceous/Paleogene boundary in age: new micropaleontological evidence. Earth and Planetary Science Letters, 249, 241-257. 
Arenillas, I., Arz, J.A., Grajales-Nishimura, J.M., Rojas-Consuegra, R. (2016). The Chicxulub impact is synchronous with the planktonic foraminifera mass extinction at the Cretaceous/Paleogene boundary: new evidence from the Moncada section, Cuba. Geologica Acta, 14(1), 35-51.

Arenillas, I., Arz, J.A. (2017). Benthic origin and earliest evolution of the first planktonic foraminifera after the Cretaceous/Paleogene boundary mass extinction. Historical Biology, 29, 17-24.

Artemieva N. et al., 2017, Quantifying the Release of Climate-Active Gases by Large Meteorite Impacts With a Case Study of Chicxulub, Geophysical Research Letters, ISSN: 0094-8276

Artemieva, N., \& Morgan, J. (2020). Global K-Pg layer deposited from a dust cloud. Geophysical Research Letters, 47(6), e2019GL086562.

Aze, T., Ezard. T.H.G., Purvis, A., Coxall, H.K., Stewart, D.R.M., Wade, B.S., \& Pearson, P.N. (2011), A phylogeny of Cenozoic macroperforate planktonic foraminifera from fossil data, Biological Reviews, 86, 900-927.

Bains, S., Norris, R.D., Corfield, R.M., \& Faul, K.L. (2000). Termination of global warmth at the Palaeocene/Eocene boundary through productivity feedback. Nature, 407, 171.

Bardeen, C. G., Garcia, R. R., Toon, O. B., \& Conley, A. J. (2017). On transient climate change at the Cretaceous - Paleogene boundary due to atmospheric soot injections. Proceedings of the National Academy of Sciences, 114(36), E7415-E7424.

Barnet, J.S., Littler, K., Westerhold, T., Kroon, D., Leng, M.J., Bailey, I., Röhl, U., \& Zachos, J. C. (2019). A high-Fidelity benthic stable isotope record of late Cretaceous-early Eocene climate change and carbon-cycling. Paleoceanography and Paleoclimatology, 34(4), 672-691.

Berggren, W. A., \& Pearson, P. N. (2005). A revised tropical to subtropical Paleogene planktonic foraminiferal zonation. The Journal of Foraminiferal Research, 35, 279-298. 
Birch, H. S., Coxall, H. K., \& Pearson, P. N. (2012). Evolutionary ecology of Early Paleocene planktonic foraminifera: size, depth habitat and symbiosis. Paleobiology, 38(3), 374-390.

Birch, H.S., Coxall, H.K., Pearson, P.N., Kroon, D., \& Schmidt, D.N. (2016). Partial collapse of the marine carbon pump after the Cretaceous-Paleogene boundary. Geology, 44, 287-290.

Boersma, A., \& Silva, I.P. (1989). Atlantic Paleogene biserial heterohelicid foraminifera and oxygen minima. Paleoceanography, 4, 271-286.

Bown, P. (1998). Calcareous nannofossil biostratigraphy (pp. 1-315). Chapman and Hall; Kluwer Academic.

Boyd, P., \& Newton, P. (1995). Evidence of the potential influence of planktonic community structure on the interannual variability of particulate organic carbon flux. Deep Sea Research Part I: Oceanographic Research Papers, 42(5), 619-639.

Boyd, P.W., \& Newton, P.P. (1999). Does planktonic community structure determine downward particulate organic carbon flux in different oceanic provinces?. Deep Sea Research Part I: Oceanographic Research Papers, 46(1), 63-91.

Boyd, P.W., \& Trull, T.W. (2007). Understanding the export of biogenic particles in oceanic waters: is there consensus? Progress in Oceanography, 72(4), 276-312.

Boyd, P.W. (2015) Toward quantifying the response of the oceans' biological pump to climate change. Frontiers of Marine Science 2, doi: 10.3389/fmars.2015.00077

Bralower, T.J., Silva, I.P. \& Malone, M.J., 2002. New evidence for abrupt climate change in the Cretaceous and Paleogene: An Ocean Drilling Program expedition to Shatsky Rise, northwest Pacific. GSA TODAY, 12, pp.4-10.

Bralower, T.J., Cosmidis, J., Heaney, P.J., Kump, L.R., Morgan, J.V., Harper, D.T., Lyons, S.L., Freeman, K.H., Grice, K., Wendler, J., Zachos, J.C., Artimieva, N., Chen, S.A., Gulick, S.P.S., House, C.H., 
Jones, H.J., Lowery, C.M., Nims, C., Schaefer, B., Thomas, E., and Vajda, V. (in revision) Origin of a global carbonate layer deposited in the aftermath of the Cretaceous-Paleogene boundary impact. Earth and Planetary Science Letters.

Brugger, J., Feulner, G., \& Petri, S. (2017). Baby, it's cold outside: Climate model simulations of the effects of the asteroid impact at the end of the Cretaceous. Geophysical Research Letters, 44, 419-427.

Buesseler, K.O. (1998). The decoupling of production and particulate export in the surface ocean. Global Biogeochemical Cycles, 12(2), 297-310.

Coccioni, R., Frontalini, F., Bancalà, G., Fornaciari, E., Jovane, L., \& Sprovieri, M. (2010). The Dan-C2 hyperthermal event at Gubbio (Italy): Global implications, environmental effects, and cause(s). Earth and Planetary Science Letters, 297, 298-305.

Collins, G.S., Patel, N., Rae, A.S., Davies, T.M., Morgan, J.V. Gulick, S.P.S. and Expedition 364 Scientists (2017). Numerical simulations of Chicxulub crater formation by oblique impact. Lunar and Planetary Science Conference XLVII, abstract \#1832.

Coxall, H.K., S. D'Hondt, \& J.C. Zachos (2006), Pelagic evolution and environmental recovery after the Cretaceous-Paleogene mass extinction, Geology, 34(4), 297-300.

Culver, S.J. (1988), New foraminiferal depth zonation of the northwestern Gulf of Mexico, Palaios, 3 , 69-85.

Culver, S. J. (2003). Benthic foraminifera across the Cretaceous-Tertiary (K-T) boundary: a review. Marine Micropaleontology, 47(3-4), 177-226.

D'Hondt, S., \& Keller, G. (1991). Some patterns of planktic foraminiferal assemblage turnover at the Cretaceous-Tertiary boundary. Marine Micropaleontology, 17, 77-118. 
D'Hondt, S., \& Zachos, J.C. (1993). On stable isotopic variation and earliest Paleocene planktonic foraminifera. Paleoceanography, 8, 527-547.

D'Hondt, S., King, J., \& Gibson, C. (1996). Oscillatory marine response to the Cretaceous-Tertiary impact. Geology, 24, 611-614.

D'Hondt, S., Donaghay, P., Zachos, J.C., Luttenberg, D., \& Lindinger, M. (1998). Organic carbon fluxes and ecological recovery from the Cretaceous-Tertiary mass extinction. Science, 282, 276-279.

D'Hondt, S., \& Zachos, J.C. (1998). Cretaceous foraminifera and the evolutionary history of planktic photosymbiosis. Paleobiology, 24, 512-523.

D'Onofrio, R., Luciani, V., Fornaciari, E., Giusberti, L., Boscolo Galazzo, F., Dallanave, E., ... \& Telch, S. (2016). Environmental perturbations at the early Eocene ETM2, H2, and I1 events as inferred by Tethyan calcareous plankton (Terche section, northeastern Italy). Paleoceanography, 31(9), $1225-1247$.

De La Rocha, C.L. \& Passow, U. (2007). Factors influencing the sinking of POC and the efficiency of the biological carbon pump. Deep Sea Research Part II: Topical Studies in Oceanography, 54(5-7), 639-658.

Dymond, J., Suess, E., \& Lyle, M. (1992). Barium in deep-sea sediment: A geochemical proxy for paleoproductivity, Paleoceanography, 7, 163-181. doi:10.1029/92PA00181

Eagle, M., Paytan, A., Arrigo, K.R., van Dijken, G., \& Murray, R.W. (2003). A comparison between excess barium and barite as indicators of carbon export, Paleoceanography, 18, 1021. doi:10.1029/2002PA000793

Edgar, K.M., Wilson, P.A., Sexton, P.F., \& Suganuma, Y., (2007) No extreme glaciation during the main Eocene calcite compensation depth shift, Nature, 448, 908-911. 
Esmeray-Senlet, S., Wright, J.D., Olsson, R.K., Miller, K.G., Browning, J.V., \& Quan, T.M. (2015). Evidence for reduced export productivity following the Cretaceous/Paleogene mass extinction, Paleoceanography, 30, doi:10.1002/2014PA002724.

Fraass, A.J., Kelly, D.C., \& Peters, S.E. (2015), Macroevolutionary history of the planktic foraminifera Annual Reviews of Earth and Planetary Science, 43, 139-166.

Francois, R., Honjo, S., Manganini, S.J., \& Ravizza, G.E. (1995). Biogenic barium fluxes to the deep sea: Implications for paleoproductivity reconstruction, Global Biogeochemical Cycles, 9, 289-303. doi:10.1029/95GB00021.

Galloway, W.E., Ganey-Curry, P.E., Li, X., \& Buffler, R.T. (2000), Cenozoic depositional history of the Gulf of Mexico basin, AAPG Bulletin, 84, 1743-1774.

Gertsch, B., Keller, G., Adatte, T., Garg, R., Prasad, V., Berner, Z., \& Fleitmann, D. Environmental effects of Deccan volcanism across the Cretaceous-Tertiary transition in Meghalaya, India, Earth and Planetary Science Letters 310 272-285 (2011).

Gibbs, S.J., Bralower, T.J., Bown, P.R., Zachos, J.C., \& Bybell, L.M. (2006). Shelf and open-ocean calcareous phytoplankton assemblages across the Paleocene-Eocene Thermal Maximum: Implications for global productivity gradients. Geology, 34, 233-236.

Gooday, A.J., (2003), Benthic Foraminifera (Protista) as tools in deep-water palaeoceanography: environmental influences on faunal characteristics, Advances in Marine Biology, 46, 1-90.

Govin, A., Holzwarth, U., Heslop, D., Ford Keeling, L., Zabel, M., Mulitza, S., Collins, J.A., \& Chiessi, C.M. (2012). Distribution of major elements in Atlantic surface sediments (36 N-49 S): Imprint of terrigenous input and continental weathering. Geochemistry, Geophysics, Geosystems, 13.

Gradstein, F.M., Ogg, J.G., Schmitz, M., \& Ogg, G., Eds. (2012), The Geologic Times Scale 2012. Elsevier B.V., Amsterdam, Netherlands. 
Griffith, E.M., \& Paytan, A. (2012). Barite in the ocean-occurrence, geochemistry and palaeoceanographic applications. Sedimentology, 59, 1817-1835.

Gulick, S.P., Barton, P.J., Christeson, G.L., Morgan, J.V., McDonald, M., Mendoza-Cervantes, K., Pearson, Z.F., Surendra, A., Urrutia-Fucugauchi, J., Vermeesch, P.M., \& Warner, M.R. (2008). Importance of pre-impact crustal structure for the asymmetry of the Chicxulub impact crater. Nature Geoscience, 1, 131.

Gulick, S., Morgan, J., Mellett, C.L., Green, S.L., Bralower, T., Chenot, E., Christeson, G., Claeys, P., Cockell, C., Coolen, M.J.L., Ferrière, L., Gebhardt, C., Goto, K., Jones, H., Kring, D., Lofi, J., Lowery, C., Ocampo-Torres, R., Perez-Cruz, L., Pickersgill, A.E., Poelchau, M., Rae, A., Rasmussen, C., Rebolledo-Vieyra, M., Riller, U., Sato, H., Smit, J., Tikoo, S., Tomioka, N., Urrutia- Fucugauchi, J., Whalen, M., Wittmann, A., Yamaguchi, K., Xiao, L., \& Zylberman, W., 2017. Site M0077: Post-Impact Sedimentary Rocks. In Morgan, J., Gulick, S., Mellett, C.L., Green, S.L., and the Expedition 364 Scientists, Chicxulub: Drilling the K-Pg Impact Crater. Proceedings of the International Ocean Discovery Program, 364: College Station, TX (International Ocean Discovery Program). https://doi.org/10.14379/iodp.proc.364.105.2017

Gulick, S.P.S., Bralower, T.J., Ormö, J., Hall, B., Grice, K., Schaefer, B., Lyons, S., Freeman, K.H., Morgan, J.V., Artemieva, N., Kaskes, P., de Graff, S.J., Whalen, M.T., Collins, S.M., Verhagen, C., Christeson, G.L., Claeys, P., Coolen, M.J., Goderis, S., Goto, K., Grieve, R., McCall, N., Osinksi, G.R., Rae, A., Riller, U., Smit, J., Vajda, V., Wittman, A., and Expedition 364 Scientists, (2019) The First Day of the Cenozoic. Proceedings of the National Academy of Sciences, 116, 19342-19351.

Hemleben, C., Spindler, M., \& Anderson, O. R. (1989). Modern planktonic foraminifera. Springer Science \& Business Media. 
Hemleben, C., Mühlen, D., Olsson, R.K., \& Berggren, W.A. (1991). Surface texture and the first occurrence of spines in planktonic foraminifera from the early Tertiary. Geologisches Jahrbuch, $128,117-146$.

Henehan, M. J., Ridgwell, A., Thomas, E., Zhang, S., Alegret, L., Schmidt, D. N., Rae, J.W.B., Witts, J.D., Landman, N.H., Greene, S.H., Huber, B.T., Super, J.R., Planavsky, N.J., \& Hull, P.M. (2019). Rapid ocean acidification and protracted Earth system recovery followed the endCretaceous Chicxulub impact. Proceedings of the National Academy of Sciences, 116(45), 2250022504.

Henson, S.A., Sanders, R., \& Madsen, E. (2012), Global patterns in efficiency of particulate organic carbon export and transfer to the deep ocean, Global Biogeochem. Cycles, 26, GB1028, doi:10.1029/2011GB004099.

Hildebrand, A.R., Penfield, G.T., Kring, D.A., Pilkington, M., Camargo, A.Z., Jacobsen, S.B., \& Boynton, W.V. (1991). Chicxulub Crater: a possible Cretaceous/Tertiary boundary impact crater on the Yucatán Peninsula, Mexico. Geology 19, 867-871.

Hsü, K.J., \& McKenzie, J.A. (1985). A “Strangelove” ocean in the earliest Tertiary. The Carbon Cycle and Atmospheric CO: Natural Variations Archean to Present, 487-492.

Hull, P.M., \& R.D. Norris (2011), Diverse patterns of ocean export productivity change across the Cretaceous-Paleogene boundary: New insights from biogenic barium, Paleoceanography, 26(3).

Hull, P. M., Norris, R. D., Bralower, T. J., \& Schueth, J. D. (2011). A role for chance in marine recovery from the end-Cretaceous extinction. Nature Geoscience, 4, 856-860.

Jablonski, D. (1995) in Extinction Rates (eds. Lawton, J. H. \& May, R. M.) 25-44 Oxford Univ. Press, Oxford. 
Jehle, S., Bornemann, A., Deprez, A., \& Speijer, R.P. (2015). The impact of the latest Danian event on planktic foraminiferal faunas at ODP site 1210 (Shatsky rise, Pacific Ocean). PloS one, 10, $\mathrm{e} 0141644$.

Jiang, S., T.J. Bralower, M.E. Patzkowsky, L.R. Kump, \&J.D. Schueth (2010), Geographic controls on nannoplankton extinction across the Cretaceous/Palaeogene boundary, Nature Geoscience, 3(4), 280.

Jones, H., Lowery, C.M., and Bralower, T. (2019). Delayed calcareous nannoplankton boom-bust successions in the earliest Paleocene Chicxulub (Mexico) impact Crater. Geology, 47 753-756 https://doi.org/10.1130/G46143.1

Jorissen, F.J., H.C. de Stigter, \& J.G.V. Widmark, (1995), A conceptual model explaining benthic foraminiferal microhabitats, Marine Micropaleontology, 26, 3-15.

Keller, G. (1989). Extended Cretaceous/Tertiary boundary extinctions and delayed population change in planktonic foraminifera from Brazos River, Texas. Paleoceanography and Paleoclimatology, 4, 287-332.

Knoll, A.H. \& Follows, M.J. (2016) A bottom-up perspective on ecosystem change in Mesozoic oceans, Proceedings of the Royal Society B 2832016755.

Kring, D. A. (2007). The Chicxulub impact event and its environmental consequences at the CretaceousTertiary boundary: Palaeogeography, Palaeoclimatology, Palaeoecology, 255, 4-21.

Lam, P.J., Doney, S.C., \& Bishop, J.K.B. (2011). The dynamic ocean biological pump: Insights from a global compilation of particulate organic carbon, $\mathrm{CaCO} 3$ and opal concentration profiles from the mesopelagic. Global Biogeochemical Cycles 27, GB3009.

Leckie, R.M., Bralower, T.J., \& Cashman, R. (2002). Oceanic anoxic events and plankton evolution: Biotic response to tectonic forcing during the mid-Cretaceous. Paleoceanography, 17, 13-1. 
Leckie, R.M., \& H.C. Olson, (2003), Foraminifera as proxies for sea-level change on siliciclastic margins, in: Olson, H.C., and R.M. Leckie, eds., Micropaleontologic proxies for sea-level change and stratigraphic discontinuities, SEPM Special Publication No. 75, 5-19.

Legendre, L., \& Michaud, J. (1998). Flux of biogenic carbon in oceans: size-dependent regulation by pelagic food webs. Marine Ecology Progress Series, 164, 1-11.

Legendre, L. \& Rivkin, R.B. (2002). Fluxes of carbon in the upper ocean: regulation by food-web control nodes. Marine Ecology Progress Series, 242, 95-109.

Lirer, F. (2000). A new technique for retrieving calcareous microfossils from lithified lime deposits. Micropaleontology 46, 365-369.

Liu, C., \& Olsson, R.K. (1992). Evolutionary radiation of microperforate planktonic foraminifera following the K/T mass extinction event. The Journal of Foraminiferal Research, 22, 328-346.

Liu, Q., Roberts, A. P., Larrasoana, J. C., Banerjee, S. K., Guyodo, Y., Tauxe, L., \& Oldfield, F. (2012). Environmental magnetism: principles and applications. Reviews of Geophysics, 50, RG4002, doi:10.1029/2012RG000393.

Lowery, C.M. et al., 2018, Rapid Recovery of Life At Ground Zero of the End Cretaceous Mass Extinction, Nature v. 558, p. 288-291, https://doi.org/10.1038/s41586-018-0163-6

Lowery, C.M. \& Fraass, A.J. (2019). Explanation for delayed recovery of species diversity following the end Cretaceous mass extinction. Nature Ecology and Evolution https://doi.org/10.1038/s41559$\underline{019-0835-0}$

Lowery, C.M., Bralower, T.J., Christeson, G., Gulick, S.P.S., Morgan, J.V., and Expedition 364 Scientists (2019). Ocean Drilling Perspectives on Meteorite Impacts. Oceanography 32, 120-134. https://doi.org/10.5670/oceanog.2019.133 
Lowery, C. M., Bown, P. R., Fraass, A. J., \& Hull, P. M. (2020). Ecological Response of Plankton to Environmental Change: Thresholds for Extinction. Annual Review of Earth and Planetary Sciences, 48.

MacLeod, K. G., Quinton, P. C., Sepúlveda, J., \& Negra, M. H. (2018). Postimpact earliest Paleogene warming shown by fish debris oxygen isotopes (El Kef, Tunisia). Science, 360(6396), 1467-1469.

Miller, K. G., Browning, J. V., Schmelz, W. J., Kopp, R. E., Mountain, G. S., \& Wright, J. D. (2020). Cenozoic sea-level and cryospheric evolution from deep-sea geochemical and continental margin records. Science advances, 6(20), eaaz1346.

Morgan, J.V., S.P.S. Gulick, C.L. Mellet, S.L. Green, \& Expedition 364 Scientists (2017) Chicxulub: Drilling the K-Pg Impact Crater, Proceedings of the International Ocean Discovery Program, 364, International Ocean Discovery Program, College Station, TX, doi: 10.14379/iodp.proc.364.103.2017.

Murray, J.W. (1976), A method of determining proximity of marginal seas to an ocean, Marine Geology, $22,103-119$.

Norris, R. D. (1996). Symbiosis as an evolutionary innovation in the radiation of Paleocene planktic foraminifera. Paleobiology, 22, 461-480.

Okada, H., and Bukry, D. (1980). Supplementary modification and introduction of code numbers to the low-latitude coccolith biostratigraphic zonation (Bukry, 1973; 1975). Marine Micropaleontology, $5,321-325$.

Olsson, R. K., Berggren, W. A., Hemleben, C. I., \& Huber, B. T. (1999). Atlas of Paleocene planktonic foraminifera. Smithsonian Contributions to Paleobiology 85.

Paytan, A., Kastner, M., and Chavez, F.P. (1996). Glacial to interglacial fluctuations in productivity in the equatorial Pacific as indicated by marine barite. Science, 274, 1355-1357. 
Paytan, A., and Griffith, E.M. (2007). Marine barite: Recorder of variations in ocean export productivity, in Encyclopedia of Paleoclimate and Ancient Environments, Gornitz, V., Ed., p. 643-651, Springer, New York.

Pearson, P.N., Olsson, R.K., Huber, B.T., Hemleben, C., and Berggren, W. A. (2006). Atlas of Eocene Planktonic Foraminifera, Cushman Foundation for Foraminiferal Research Special Publications, vol. 41. Washington, DC, 513.

Pedersen, T. F., \& Calvert, S. E. (1990). Anoxia vs. productivity: what controls the formation of organiccarbon-rich sediments and sedimentary Rocks?. AAPG Bulletin, 74(4), 454-466.

Perch-Nielsen, K. (1985). Cenozoic calcareous nannofossils. In Bolli, H.M., Saunders, J.B., and PerchNielsen, K. (Eds.) Plankton stratigraphy, Cambridge: Cambridge University Press. 427-554.

Pope, K. O., Baines, K. H., Ocampo, A. C., \& Ivanov, B. A. (1994). Impact winter and the Cretaceous/Tertiary extinctions: Results of a Chicxulub asteroid impact model. Earth and Planetary Science Letters, 128(3-4), 719-725.

Punekar, J., Mateo, P., \& Keller, G. (2014a) Effects of Deccan volcanism on paleoenvironment and planktic foraminifera: A global survey, Geological Society of America Special Papers, 505, 91-116.

Punekar, J., Keller, G., Khozyem, H., Hamming, C., Adatte, T., Tantawy, A.A., \& Spangenberg, J.E. (2014b) Late Maastrichtian-early Danian high-stress environments and delayed recovery linked to Deccan volcanism, Cretaceous Research, 49, 63-82.

Quillévéré, F., Norris, R.D., Kroon, D., and Wilson, P.A. (2008). Transient ocean warming and shifts in carbon reservoirs during the early Danian. Earth and Planetary Science Letters, 265, 600-615.

Renne, P.R., Sprain, C.J., Richards, M.A., Self, S., Vanderkluysen, L., \& Pande, K. (2015) State shift in Deccan volcanism at the Cretaceous-Paleogene boundary, possibly induced by impact, Science, 350, 76-78. 
Rodriguez-Tovar, F. J., Lowery, C. M., Bralower, T. J., Gulick, S. P. S., \& Jones, H. L. (in revision) Rapid microbenthic diversification and stabilization after the end-Cretaceous mass extinction event. Geology.

Rothwell R., \& Croudace I. (2015). Twenty Years of XRF Core Scanning Marine Sediments: What Do Geochemical Proxies Tell Us?. In: Croudace I., Rothwell R. (eds) Micro-XRF Studies of Sediment Cores. Developments in Paleoenvironmental Research, 17. Springer, Dordrecht

Schaefer, B. Grice, K., Coolen, M.J.L., Summons, R.E., Cui, X., Bauersachs, T., Schwark, L., Böttcher, M.E., Bralower, T.J., Lyons, S.L., Freeman, K.H., Cockell, C.S., Gulick, S.P.S., Morgan, J.V., Whalen, M.T., Lowery, C.M., and Vajda, V. (2020) Microbial life in the nascent Chicxulub crater. Geology. 48, https://doi.org/10.1130/G46799.1

Schoene, B., Eddy, M. P., Samperton, K. M., Keller, C. B., Keller, G., Adatte, T., \& Khadri, S. F. (2019). $\mathrm{U}-\mathrm{Pb}$ constraints on pulsed eruption of the Deccan Traps across the end-Cretaceous mass extinction. Science, 363(6429), 862-866.

Schueth, J. D., T. J. Bralower, S. Jiang, and M. E. Patzkowsky (2015), The role of regional survivor incumbency in the evolutionary recovery of calcareous nannoplankton from the Cretaceous/Paleogene (K/Pg) mass extinction, Paleobiology, 41(4), 661-679.

Schulte, P. and 40 others, (2010), The Chicxulub asteroid impact and mass extinction at the CretaceousPaleogene boundary, Science, 327, 1214-1218.

Sepúlveda, J., Wendler, J.E., Summons, R.E., \& Hinrichs, K.U. (2009). Rapid resurgence of marine productivity after the Cretaceous-Paleogene mass extinction. Science, 326, 129-132.

Sigman, D. M. \& Hain, M. P. (2012) The Biological Productivity of the Ocean. Nature Education Knowledge 3, p. 21

Smit, J. and J. Hertogen (1980). An extraterrestrial event at the Cretaceous-Tertiary boundary, Nature 285: 198-200. 
Sprain, C. J., Renne, P. R., Vanderkluysen, L., Pande, K., Self, S., \& Mittal, T. (2019). The eruptive tempo of Deccan volcanism in relation to the Cretaceous-Paleogene boundary. Science, 363(6429), 866870.

Tabor, C.R., Bardeen, C.G., Otto-Bliesner, B.L., Garcia, R.R., \& Toon, O.B. (2020). Causes and Climatic Consequences of the Impact Winter at the Cretaceous-Paleogene Boundary. Geophysical Research Letters, 47, e60121.

Thunell, R.C. (1976). Optimum indices of calcium carbonate dissolution, in deep-sea sediments. Geology, $4,525-528$.

Troelsen, J.C. (1957). Some planktonic foraminifera of the type Danian and their stratigraphic importance. US National Museum Bulletin, 215, 125-131.

Tschudy, R. H., Pillmore, C. L., Orth, C. J., Gilmore, J. S., \& Knight, J. D. (1984). Disruption of the terrestrial plant ecosystem at the Cretaceous-Tertiary boundary, Western Interior. Science, 225(4666), 1030-1032.

Tsikos, H., Jenkyns, H.C., Walsworth-Bell, B., Petrizzo, M.R., Forster, A., Kolonic, S., Erba, E., Silva, I.P., Baas, M., Wagner, T., \& Damsté, J.S. (2004). Carbon-isotope stratigraphy recorded by the Cenomanian-Turonian Oceanic Anoxic Event: correlation and implications based on three key localities. Journal of the Geological Society, 161(4), 711-719.

Vajda, V., Raine, J. I., Hollis, C. J., \& Strong, C. P. (2004). Global effects of the Chicxulub impact on terrestrial vegetation - review of the palynological record from New Zealand Cretaceous/Tertiary boundary. In Cratering in marine environments and on ice (pp. 57-74). Springer, Berlin, Heidelberg.

Van der Zwaan, G.J., Jorissen, F.J. \& Stitger, H.C. (1990), The depth dependency of planktonic/benthic foraminiferal ratios: constraints and applications, Marine Geology, 95, 1-16. 
Van Hinsbergen, D.J.J., Kouwenhoven, T.J., \& Van der Zwaan, G.J. (2005), Paleobathymetry in the backstripping procedure: correction of oxygenation effects on depth estimates, Palaeogeography, Palaeoclimatology, Palaeoceology, 21, 245-265.

Vellekoop, J., Sluijs, A., Smit, J., Schouten, S., Weijers, J.W.H., Sinninghe Damsté, J.S., \& Brinkhuis, H., (2014). Rapid short-term cooling following the Chicxulub impact at the Cretaceous-Paleogene boundary. PNAS, 111, 7537-7541.

Vellekoop, J., Woelders, L., Açikalin, S., Smit, J., Van De Schootbrugge, B., Yilmaz, I.O., Brinkhuis, H., \& Speijer, R. (2017). Ecological response to collapse of the biological pump following the mass extinction at the Cretaceous-Paleogene boundary. Biogeosciences, 14, 885-900.

Wade, B.S., Pearson, P.N., Berggren, W.A., \& Pälike, H. (2011). Review and revision of Cenozoic tropical planktonic foraminiferal biostratigraphy and calibration to the geomagnetic polarity and astronomical time scale. Earth-Science Reviews, 104, 111-142.

Wolbach, W. S., Lewis, R. S., \& Anders, E. (1985). Cretaceous extinctions: evidence for wildfires and search for meteoritic material. Science, 230(4722), 167-170.

Zachos, J.C., Arthur, M.A., \& Dean, W.E. (1989). Geochemical evidence for suppression of pelagic marine productivity at the Cretaceous/Tertiary boundary. Nature, 337, 61-64.

Zhang, C., Dang, H., Azam, F., Benner, R., Legendre, L., Passow, U., Polimene, L., Robinson, C., Suttle, C.A., \& Jiao, N. (2018). Evolving paradigms in biological carbon cycling in the ocean. National Science Review 5, 481-499.

Ziegler M., Lourens L. J., Tuenter E., \& Reichart G. J. (2009). Anomalously high Arabian Sea productivity conditions during MIS 13. Climate of the Past Discussion 5:1989-2018. (www.clim-pastdiscuss.net/5/1989/2009/) 